Boston University School of Law

Scholarly Commons at Boston University School of Law

Faculty Scholarship

4-2017

\title{
The Practice and Tax Consequences of Nonqualified Deferred Compensation
}

David I. Walker

Boston University School of Law

Follow this and additional works at: https://scholarship.law.bu.edu/faculty_scholarship

Part of the Labor and Employment Law Commons, and the Tax Law Commons

\section{Recommended Citation}

David I. Walker, The Practice and Tax Consequences of Nonqualified Deferred Compensation, in No. 16-27 Boston University School of Law, Law and Economics Research Paper (2017).

Available at: https://scholarship.law.bu.edu/faculty_scholarship/806

This Article is brought to you for free and open access by Scholarly Commons at Boston University School of Law. It has been accepted for inclusion in Faculty Scholarship by an authorized administrator of Scholarly Commons at Boston University School of Law. For more information, please contact lawlessa@bu.edu. 


\title{
BU School of Law
}

\section{The Practice AND TAX CONSEQUENCES OF NONQUALIFIED DEFERRED COMPENSATION}

\author{
Boston University School of Law \\ Law \& Economics Working Paper No. 16-27
}

April 21, 2017

\section{David I. Walker}

Boston University School of Law

This paper can be downloaded without charge at: 


\title{
The Practice and Tax Consequences of Nonqualified Deferred Compensation
}

\author{
David I. Walker*
}

\begin{abstract}
Although nonqualified deferred compensation plans lack explicit tax preferences afforded qualified plans, it is well understood that nonqualified deferred compensation results in a joint tax advantage when employers earn a higher after-tax return on deferred sums than employees could achieve on their own. Several commentators have proposed tax reform aimed at leveling the playing field between cash and nonqualified deferred compensation, but reform is not easily achieved. This Article examines the stakes. It investigates private sector nonqualified deferred compensation practices and shows that joint tax minimization often takes a backseat to accounting priorities and participant diversification concerns. In practice, the largest source of joint tax advantage likely stems from use of corporate owned life insurance (COLI) to informally fund nonqualified deferred compensation liabilities, suggesting that narrow reform aimed at COLI use might be a more attractive policy response than fundamental reform of the taxation of nonqualified deferred compensation.
\end{abstract}

\footnotetext{
${ }^{*}$ Professor of Law and Maurice Poch Faculty Research Scholar, Boston University School of Law. Acknowledgments to follow. Draft of April 21, 2017. Please do not cite without author's permission.
} 


\section{Table of Contents}

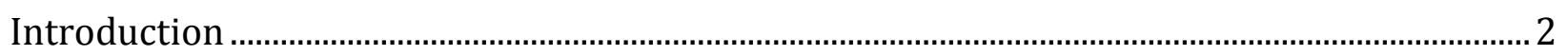

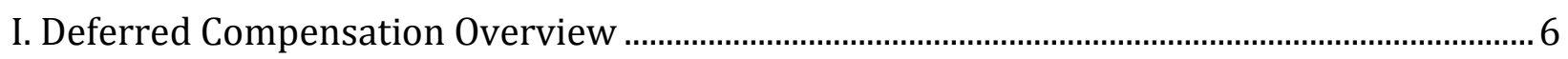

A. Qualified Deferred Compensation Plans and Taxation................................................................ 6

B. Nonqualified Deferred Compensation Arrangements ........................................................... 8

C. Nonqualified Deferred Compensation Taxation.................................................................... 10

D. Nonqualified Deferred Compensation Accounting ………………………………………….. 13

E. Efficient Asset Allocation and Other Features of Nonqualified Deferred Compensation

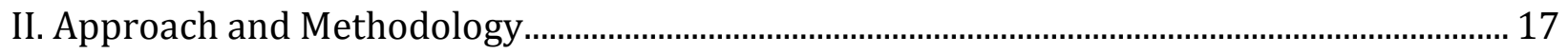

III. Nonqualified Deferred Compensation in Practice.................................................................... 21

A. Participation and Source of Funds......................................................................................... 21

B. Participant Notional Investment........................................................................................... 22

C. Informal Funding By Plan Sponsors................................................................................... 26

D. Joint Tax Consequences of Nonqualified Plans in Practice...................................................... 32

1. Defined Contribution Plans................................................................................................. 34

2. Defined Benefit Plans ………………............................................................................... 36

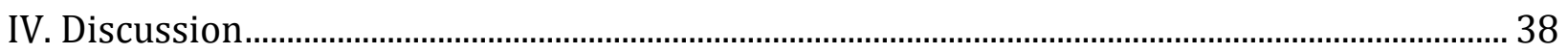

A. Is There a Joint Tax Advantage Issue to Worry About, and, If So, What Is It? .................. 38

B. What Are the Distributional Consequences of Deferred Compensation? .......................... 44

C. What Role Do Taxes Play in the Adoption or Operation of Nonqualified Deferred

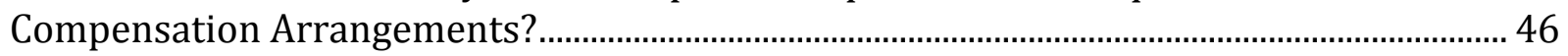

D. Why (Else) Do Firms Offer Nonqualified Deferred Compensation?.................................... 48

E. A Final Mystery? Relative Use of Own-Company Stock in Qualified and Nonqualified Deferred Compensation Plans.......................................................................................................... 50

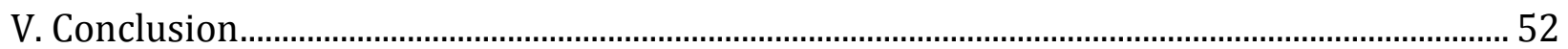

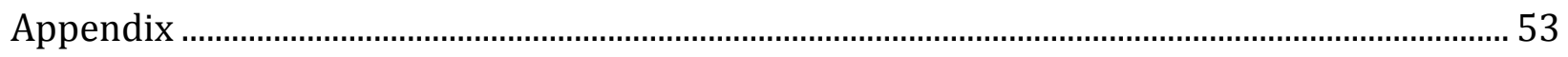




\section{Introduction}

Executives and other high-level corporate employees often receive compensation relating to current services that is payable in future years. This deferred compensation might consist of "long-term" incentive compensation (both equity and non-equity based arrangements) that generally pays out several years after grant. Compensation also may be deferred through qualified plans, explicitly tax-preferred arrangements that include traditional, qualified defined-benefit pension plans and qualified defined-contribution plans, such as 401(k)s. ${ }^{1}$ This article focuses on a third class of deferred compensation writ large, the nonqualified analogs of qualified plans, generally referred to as nonqualified deferred compensation. ${ }^{2}$

Nonqualified deferred compensation plans have a long history in the U.S. and they remain popular today. ${ }^{3}$ These plans take a variety of forms, including both defined-benefit and defined-contribution arrangements. Often these plans supplement or extend the benefits provided to qualified plan participants, but this is not always the case. Perhaps most familiar are elective deferred compensation plans, which allow participants to defer a portion of their salary, bonus, or other compensation, and defer the tax on that compensation, until a future date, often until retirement. 4

\footnotetext{
${ }^{1}$ As discussed infra Part I.A., participants in defined benefit plans are promised specified benefits at retirement, e.g., an annuity equal to a percentage of pre-retirement wages; defined contribution plans specify annual contributions that yield benefits at retirement that depend on the investment choices of the parties.

2 There is no authoritative definition of nonqualified deferred compensation. I.R.C. $\S 409 \mathrm{~A}$ defines a nonqualified deferred compensation plan as any plan providing for the deferral of compensation other than a qualified plan. I.R.C. $§ 409 A(d)(1)$ (2012). Under this definition, stock options and other long-term equity-based pay would be considered nonqualified deferred compensation. The present Article, however, generally excludes equity incentive pay from the definition of nonqualified deferred compensation, in keeping with more standard industry terminology.

3 Approximately three quarters of large companies offer nonqualified deferred compensation programs currently. Doug Frederick \& AARon PEdowitz, MERCER, MARKet LANDSCAPE OF EXECUTIVE BENEFIT PROGRAMS 2 (Feb. 26, 2016) (reporting that 73\% of Fortune 500 companies offered nonqualified savings plans in 2015); THE NEWPORT GROUP, EXECUTIVE BENEFITS: A SuRVEY OF CURRENT TRENDS 13 (2014/2015 Edition) [hereinafter Newport Group Survey] (72\% of Fortune 1000 companies offered a nonqualified savings plan in 2013).

Some governmental entities and other tax-exempt organizations also offer nonqualified savings opportunities. The use of nonqualified deferred compensation by these organizations is not a focus of this Article.

4 Taxation is deferred only if the terms of the deferred compensation arrangement do not run afoul of the constructive receipt, cash equivalence, and economic benefit doctrines, and, since 2004, the requirements of I.R.C. $§ 409 A$. See infra text accompanying notes 40-47.
} 
Although nonqualified deferred compensation plans lack explicit tax preferences afforded qualified plans, ${ }^{5}$ it is well understood that nonqualified deferred compensation can be tax advantaged in some circumstances. The comparison that is generally made is between 1) a payment of current cash compensation that is taxed to the employee and deducted by the employer, followed by employee investment of the after-tax amount until some future date and 2) deferral of current compensation, investment by the employer, and payout at a future date resulting at that time in taxation of the employee and a deduction for the employer. Ignoring potential changes in tax rates over time, nonqualified deferred compensation results in a joint (sometimes called "global") tax advantage to an employee and employer if the employer is able to earn a higher after-tax rate of return than the employee is able to earn on her own. ${ }^{6}$ This circumstance can arise any time that the employer's tax rate on an investment is less than the employee's rate on the same investment (assuming both can access the investment), but is particularly pronounced when the investment under consideration is in the employer's own stock. In that case, an employee would be taxed with respect to her outside investment in her own company's stock at the regular rates applied to dividends and capital gains, but a firm faces no tax on gains or losses on holdings of its own stock under a particular rule of the federal income tax code, IRC $\S 1032 .{ }^{7}$

Participants in defined contribution nonqualified deferred compensation plans generally are permitted to control the notional investment of their account balances, similar to the way in which participants manage 401(k) investments, but these notional investments and the actual investments of deferred amounts by employer sponsors, if any, are not disclosed to investors. ${ }^{8}$ Finance theory suggests that poorly diversified executives should not voluntarily tie nonqualified deferred compensation account balances to their own companies' stock prices. ${ }^{9}$ However, recent scholarship suggests that they often do so ${ }^{10}$ and that employers commonly invest deferred amounts in their own stock, as well. ${ }^{11}$ If so, and given $\S 1032$,

${ }^{5}$ Qualified plan taxation is discussed infra Part I(A).

${ }^{6}$ Infra Part I(C).

${ }^{7}$ Infra Part I(C). The joint tax advantage is also large in cases in which the plan sponsor is tax exempt or effectively tax exempt. However, employees of governmental and non-profit entities have only limited access to tax deferred savings opportunities. Infra note 180 and accompanying text.

8 The term "notional investment" refers to the fact that nonqualified plan participants do not direct the investment of any actual assets but instead select a benchmark or benchmarks for the determination of the amounts contractually due to them at payout. Infra Part I(B).

${ }^{9}$ Infra text accompanying notes 71-72.

${ }_{10}$ Robert J. Jackson \& Colleen Honigsberg, The Hidden Nature of Executive Retirement Pay, 100 VA. L. REV. 479, 492 (2014).

11 Michael Doran, The Puzzle of Non-Qualified Retirement Pay: Optimal Contracting, Managerial Power, and Taxes 28 (Univ. of Va. Sch. of Law Pub. Law and Legal Theory Research Paper Series 2016-13, Working Paper, Feb. 1, 2016). 
nonqualified deferred compensation arrangements could be generating significant joint tax benefits for participants and employers, and these joint tax benefits might justify a change in the taxation of nonqualified deferred compensation, as several commentators have proposed. ${ }^{12}$

But there are obstacles to reforming the taxation of nonqualified deferred compensation, ${ }^{13}$ and, against that backdrop, this Article investigates the strength of the driving force behind tax reform. It asks whether private sector nonqualified deferred compensation plans are being operated in such a way as to generate joint tax advantages, subsidizing the compensation of high-income individuals, and potentially distorting executive pay arrangements.

This Article investigates notional participant investment of nonqualified deferred compensation balances, actual employer investment of deferred amounts, and other facts on the ground that allow one to assess the joint tax consequences of nonqualified deferred compensation arrangements as they currently function. ${ }^{14}$ Insights are derived from several industry surveys and proxy statement disclosures, as well as interviews with a number of individuals with extensive experience in the design and administration of nonqualified deferred compensation plans. Key findings, and implications, include the following: 15

- Notional investment by nonqualified deferred compensation plan participants in the stock of their own companies appears to be modest, and employer informal funding of nonqualified deferred compensation liabilities with own-company stock even more so. As a result, § 1032 apparently provides little joint tax advantage for nonqualified deferred compensation arrangements.

- Corporate owned life insurance (COLI) products are used to informally fund a quarter or more of aggregate nonqualified deferred compensation account balances. COLI use can result in a large joint tax advantage, but the tax advantage is offset to some degree by the cost of insurance and administrative costs.

\footnotetext{
12 See Michael Doran, Executive Compensation Reform and the Limits of Tax Policy, THE URBAn-Brookings TAX Policy CTR., Nov. 2004, at 14; Daniel I. Halperin, Interest in Disguise: Taxing the "Time Value of Money", 95 YALE L.J. 506, 539 (1986); Ethan Yale \& Gregg D. Polsky, Reforming the Taxation of Deferred Compensation, 85 N.C. L. REV. 571, 574 (2007); Daniel I. Halperin \& Ethan Yale, Deferred Compensation Revisited 114 TAX Notes 939, 941 (Mar. 5, 2007).

13 Infra Part II.

14 One might argue that potential joint tax consequences are also important or more important than actual tax consequences. Infra Part IV(A).

15 Infra Part III.
} 
- Other nonqualified plan liabilities are funded using taxable securities (often held in rabbi trusts) or remain unfunded liabilities with the deferred amounts being used in the business or to reduce borrowing. In either case, and setting aside employers facing low effective marginal tax rates, the joint tax consequences range from modest advantage to modest disadvantage and are likely to be roughly neutral in aggregate.

The joint tax consequences of nonqualified deferred compensation do not appear to be of first order importance in the decision to adopt these plans, and while certain tax considerations clearly matter in operation (e.g., avoiding tax penalties on non-complying deferred compensation plans under IRC § 409A), ${ }^{16}$ participants and plan sponsors do not appear to be making investment decisions with a view to minimizing their joint tax burden. ${ }^{17}$ As a result, it is not clear that fundamental reform of nonqualified deferred compensation is required. A more surgical approach targeting the use of COLI might be a better response. ${ }^{18}$

Why don't firms and employees make tax-minimizing investment decisions within nonqualified deferred compensation programs? It appears that financial accounting and participant diversification concerns often trump joint taxminimization. ${ }^{19}$ In elective defined contribution plans, participants tend to select diversified equity and debt funds that create volatile liabilities on corporate financial statements. To the extent that they informally fund their obligations within these plans, sponsors tend to mirror the aggregate notional investment choices of participants in order to hedge their economic exposure, as well as financial statement volatility, even when the joint tax consequences are neutral or disadvantageous. Notional participant investment in own-company stock, by contrast, undermines participant diversification needs and also creates liabilities that cannot be perfectly hedged from an income statement perspective. The combined effect appears to discourage the use of own-company stock in such plans.

But what about firms that face a low effective marginal rate because of accumulated losses? These firms could invest deferred participant dollars in essentially any manner and create a joint tax advantage. Despite the potential tax savings, preliminary evidence suggests that nonqualified deferred compensation participation at these firms is an order of magnitude less than at firms facing high effective rates. Perhaps the risk associated with an unsecured promise to deliver deferred compensation outweighs the potential tax savings at these firms.

\footnotetext{
16 Infra Part I(C).

${ }_{17}$ As discussed infra Part IV.A.2, extensive use of COLI to informally fund nonqualified deferred compensation is in itself evidence that the parties often do not minimize joint tax costs through investment decisions. If firms and participants minimized joint tax through use of own-company stock, for example, there would be no need to acquire expensive COLI products.

18 Infra Part IV(A).

${ }^{19}$ Infra Part III.
} 
Whatever the explanation, low effective rate firms do not appear to be fully exploiting the nonqualified deferred compensation opportunity.

This Article also considers the distributional consequences of nonqualified deferred compensation. ${ }^{20}$ Despite the lack of a clear joint tax advantage at high tax firms, this Article argues that the after-tax returns achieved by nonqualified deferred compensation participants substantially exceed those available on equivalent outside investments, and that it is unlikely that these effective abovemarket returns are shifted back to firms through other adjustments to compensation. Shareholders, in other words, likely bear the cost of these abovemarket returns, not the public fisc.

The remainder of the Article is organized as follows. Part I provides an overview of qualified and nonqualified deferred compensation. Part II briefly describes the approach and methodology of the present Article. Part III provides survey and interview evidence concerning nonqualified deferred compensation practices and uses that evidence to estimate the aggregate joint tax consequences of nonqualified plans at high rate firms in practice. Part IV discusses the implications of these findings for high effective rate firms, investigates use of nonqualified deferred compensation by low rate firms, addresses distributional consequences, and considers non-joint tax minimization explanations for the persistence of nonqualified deferred compensation, including path dependence and stealth compensation for executives. Part V concludes with a call for reassessment of COLI use and taxation and for enhanced disclosure of effectively above-market nonqualified deferred compensation returns.

\section{Deferred Compensation Overview}

This Part begins with a brief description of qualified plans before moving on to description and overview of the tax, accounting, and governance features of nonqualified plans. This Part also highlights prior research that addresses the tax consequences of nonqualified deferred compensation.

\section{A. Qualified Deferred Compensation Plans and Taxation}

Congress has provided preferential tax treatment for qualified deferred compensation plans in order to encourage companies to create these plans and to encourage employees to save for retirement. Qualified plans are intended to be broadly based and are subject to nondiscrimination requirements ${ }^{21}$ and limits on

\footnotetext{
20 Infra Part IV.B.

${ }^{21}$ I.R.C. $\S \S 401(a)(4), 410(b)$. These requirements are designed to ensure that plans do not discriminate in favor of highly compensated employees. See EMPLOYEE BENEFIT RESEARCH Institute, Fundamentals of Employee Benefit PRograms 46 (6th ed. 2009) [hereinafter, EBRI).
} 
contributions, benefits, and the amount of an employee's compensation that may be taken into account for purposes of a qualified plan. ${ }^{22}$

Qualified plans may be structured as defined benefit (DB) plans or defined contribution (DC) plans. DB plans promise participants specified benefits at retirement. Often the benefit is structured as an annuity and represents some fraction of a participant's pre-retirement wage rate. ${ }^{23}$ The plan sponsor (the employer) makes contributions to a pension trust and directs the investment of trust assets to satisfy plan obligations. ${ }^{24}$ Participants are essentially passive beneficiaries.

Defined contribution plans, such as 401(k) plans, also involve contributions to a trust, but participants generally direct the investment of their own accounts within the trust based on a menu of investment options provided by the plan sponsor and administrator. ${ }^{25}$ Both participants and employers may make contributions to DC accounts. Employer contributions often are structured as matching contributions. Benefits ultimately are a function of the amounts contributed and the investment choices made by participants.

While qualified DB plans were once very common in the U.S. - and hence constitute what many older Americans think of as corporate pensions - many firms have phased out DB plans, generally replacing them with DC plans. ${ }^{26}$ At the end of 2015 , assets in private qualified DB plans totaled $\$ 3.1$ trillion, while private qualified DC assets totaled $\$ 5.4$ trillion. ${ }^{27}$

\footnotetext{
22 See I.R.C. $\S$ 402(g) (2012) (limiting the maximum salary deferral for eligible employees using tax qualified plans to $\$ 18,000)$; I.R.C. $\S 414(\mathrm{v})(2012)$ (allowing for an additional $\$ 6,000$ "catch-up" contribution for eligible employees over age 50); I.R.C. 401(a)(17) (limiting the annual amount of eligible salary to be considered under a tax-advantaged plan to $\$ 265,000$ ); EBRI, supra note 21 , at 50 . Most, but not all, of these restrictions were imposed by the Employee Retirement Income Security Act of 1974 (ERISA).

23 EBRI, supra note 21, at 44.

${ }^{24}$ Management of trust investments is subject to a general prudent man fiduciary duty standard; however, ERISA limits investment in plan sponsor stock to $10 \%$ of total DB trust assets. 29 U.S.C. $§ 1107$ (a) (2012).

$25401(\mathrm{k})$ and the nonprofit analog 403(b) plans are perhaps most familiar, but DC plans also include other profit-sharing plans, employee stock ownership plans (ESOPs), and other arrangements. EBRI, supra note 21, at 45.

${ }^{26}$ Doug Frederick \& Aaron Pedowitz, Mercer, Market Landscape of Executive Benefit PROGRAMS 2 (Feb. 26, 2016) (providing data indicating that $22 \%$ of Fortune 500 companies currently maintain a qualified DB plan that is open to new employees, while $99 \%$ offer qualified DC savings opportunities).

27 Fed. Reserve, Statistical Release, Financial Accounts of the United States, 4TH Quarter 201593 (released Mar. 10, 2016). DB plans have been more persistent in the public sector. See John G. Kilgour, Section 457 Deferred Compensation Plans, 45 Comp. \& BENEFITS REV. 176, 176 (2013) (noting that $87 \%$ of state and $83 \%$ of local government employees had access to a traditional DB pension plan in 2010).
} 
The taxation of qualified DC and DB plans is the same. In a nutshell, participants can contribute pre-tax dollars to a qualified plan trust. ${ }^{28}$ Employer contributions on behalf of participants are immediately deductible and excludable by the participants. ${ }^{29}$ Trust assets grow tax-free. ${ }^{30}$ Participants generally are taxed at ordinary rates when they receive benefits. ${ }^{31}$ As Professors Daniel Halperin and Alvin Warren have described, the key to the joint tax benefit of qualified deferred compensation is the exemption from tax of the income and gains that accrue to the trust between contribution and withdrawal. ${ }^{32}$ The deferral of income inclusion by participants actually has no impact on the joint tax advantage, assuming that tax rates are unchanged over time. ${ }^{33}$

\section{B. Nonqualified Deferred Compensation Arrangements}

Modestly compensated rank and file employees may be able to secure adequate retirement income streams through social security and participation in qualified plans alone, but given the income-based limitations on qualified plan participation, this is unlikely to be the case for more highly compensated employees and executives. In order to secure an adequate retirement income, these individuals must invest additional after-tax dollars on their own account or participate in company sponsored savings plans that lack the explicit tax preferences of qualified plans, i.e., nonqualified deferred compensation.

Nonqualified deferred compensation plans come in the same two basic flavors as qualified plans: defined benefit and defined contribution plans. A nonqualified DB plan may supplement a qualified DB plan, providing benefits beyond the limits imposed on qualified plans under the tax code (often called a supplemental executive retirement plan), or a nonqualified DB plan may exist

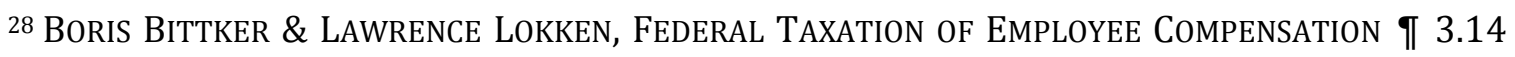
(2016), available at Thomson Reuters Checkpoint (citing I.R.C. § 402(a) (2012)).

This paragraph describes the taxation of "conventional" DC plans, such as IRAs and 401k's. Under the Roth alternative, participants contribute after-tax dollars, but payouts are free from tax. It is widely understood that if tax rates are consistent, conventional and Roth accounts yield equivalent results. See Halperin \& Warren, supra note 32, at 325 (also noting that effective contribution limits differ between Roth and conventional DC plans).

${ }^{29}$ BITTKER \& LOKKEN, supra note 28, at 93.14 (citing I.R.C. § 402(a) (2012)).

30 BITTKER \& LOKKEN, supra note 28, at 13.16 (citing I.R.C. §§ 401(a), 501(a)).

${ }^{31}$ I.R.C. $\S \S 402(a), 72(a)(1)$; EBRI, supra note 21, at 43. There is an exception to ordinary income tax treatment that applies when participants receive company stock in kind. Infra note 223.

${ }^{32}$ Halperin, supra note 12, at 539; Daniel I. Halperin \& Alvin C. Warren, Understanding Income Tax Deferral, 67 TAX L. REV. 317, 324 (2014).

33 This counterintuitive result reflects the same mechanism that leads to the equivalence of Roth and conventional IRAs, under standard assumptions. Halperin \& Warren, supra note 32 , at 325 .
} 
independently of any qualified plan. Like qualified DB plan participants, nonqualified DB participants are largely passive beneficiaries. ${ }^{34}$

Similarly, a nonqualified DC plan may supplement a company's 401(k) plan, or it might exist independently of any qualified plan. Nonqualified DC plans frequently provide for elective deferrals by executives, but companies may also match these contributions to some extent or make independent contributions to nonqualified DC accounts. ${ }^{35}$ Account balances - the amounts promised to participants - rise or fall each year based on the notional "investment" decisions of participants. These account balances are paid out to participants at a predetermined time or on a pre-determined schedule.

To be clear, unlike the owner of a 401(k) account, a nonqualified DC plan participant does not direct the investment of actual assets. The notional investment decisions of nonqualified DC participants simply determine the amounts that plan sponsors are contractually obligated to deliver at payout. Also, unlike qualified plan contributions, there is no legal requirement that sponsors of nonqualified DB or DC plans set aside assets or invest them in any particular fashion.

As detailed below, nonqualified plans lack the tax advantages associated with qualified plans. Nonetheless, it is common for firms to promise participants similar or identical benefits. ${ }^{36}$ Again, this is simply a contract between participant and firm. For example, participants in a nonqualified 401(k) match plan may be allowed to notionally invest their deferred compensation dollars and any company contributions in the same funds that are available to $401(\mathrm{k})$ investors and receive returns on their notional investments that are undiminished by tax during the deferral period; i.e., tax-free growth. The only limitations on the amount or percentage of income that may be deferred by nonqualified plan participants are contractual.

As in the qualified plan world, firms are shifting from nonqualified DB plans to nonqualified DC plans. These trends are related. A company that discontinues its qualified pension plan is less likely to maintain a nonqualified supplemental plan. One source indicates that only $25 \%$ of Fortune 500 companies allowed new hires to participate in nonqualified DB plans in 2015, down from 38\% that did so just five years earlier. ${ }^{37}$ Meanwhile, $64 \%$ of the Fortune 500 offered a nonqualified DC plan

\footnotetext{
34 Robert A. Miller, ExeCutive Compensation 215-16 (Yale D. Tauber \& Donald R. Levy eds., 2002).

35 MILLER, supra note 34, at 215-16.

36 MILLER, supra note 34, at 215-16.

37 Mercer, supra note 26, at 2. See also The NEWPort Group, ExeCutive BenEFits: A SuRvey of CURRENT TRENDS 41 (2014/2015 Edition) [hereinafter Newport Group Survey] (30\% of survey respondents report an active DB supplemental plan in 2013; 20\% of Fortune 1000 report an active DB supplemental plan).
} 
in 2015.38 However, given grandfathering, almost half of Fortune 500 executives continued to accrue benefits in a nonqualified DB plan in 2015. ${ }^{39}$

\section{Nonqualified Deferred Compensation Taxation}

When properly designed, a nonqualified deferred compensation arrangement results in deferral of participant inclusion (and employer deduction) of deferred payments until the payments are received. In the interim, the employer will pay tax at its regular rate on any income arising from its use of the deferred funds. Several doctrines, including constructive receipt, cash equivalence, and the economic benefit rule, might be invoked to require employee inclusion in the year of deferral, or at some point between deferral and payout, if access to deferred amounts is not sufficiently limited or if the arrangement too closely resembles cash compensation. ${ }^{40}$

In order to achieve tax deferral, a nonqualified deferred compensation obligation must represent only an "unfunded and unsecured promise to pay money or property in the future," 41 and participants must be "general unsecured creditors" 42 of the employer. In the wake of the Enron fiasco and several other perceived abuses of nonqualified deferred compensation arrangements, ${ }^{43}$ Congress enacted legislation in 2004 to tighten the rules and put in place severe penalties for noncompliance. That legislation, codified as IRC $\S 409 \mathrm{~A}$, constrains the timing of elective deferrals, how assets are held, and payout decisions. To comply with $\S 409 \mathrm{~A}$, deferral elections generally must be made prior to the beginning of the tax

\footnotetext{
38 Mercer, supra note 26, at 2. See also Newport Group Survey, supra note 37, at 13 (78\% of survey respondents and 72\% of Fortune 1000 offered a nonqualified DC plan in 2013).

${ }^{39}$ Mercer, supra note 26, at 2. Use of nonqualified DB plans is not random. One source suggested utilities, for example, are more likely to maintain DB plans than other firms. Telephone Interview with Executive Benefits Consultants with an International Firm (Feb. 17, 2016). Jackson and Honigsberg found that DB obligations constituted $56 \%$ of total public company top 5 executive nonqualified deferred compensation benefits. Robert J. Jackson \& Colleen Honigsberg, The Hidden Nature of Executive Retirement Pay, 100 VA. L. REV. 479, 492 (2014).

40 Miller, supra note 34, at 259-66; Gregg D. Polsky, Fixing Section 409A: Legislative and Administrative Options, 57 VILL. L. REv. 635, 638 (2012) (to avoid application of the constructive receipt doctrine deferral elections must occur before the related services are performed and must be irrevocable; to avoid application of the economic benefit doctrine, the participant must remain in the position of a general unsecured creditor).

41 Treas. Reg. $\S 1.83-3(\mathrm{e})$ (2014) (excluding such promises from the definition of property, the transfer of which would be immediately taxable under I.R.C. § 83).

42 This is one of several requirements that must be satisfied to achieve an advance ruling from the IRS that a nonqualified deferred compensation arrangement will not run afoul of the constructive receipt doctrine. Rev. Proc. 92-65, 1992-2 C.B. 428.

43 See Polsky, supra note 40, at 641 for a discussion of purported abuses of nonqualified deferred compensation at Enron.
} 
year in which the amounts are earned. ${ }^{4}$ Payout options are limited to death, disability, separation from service, change in control, unforeseeable emergency, or a date or schedule determined at the time of deferral. ${ }^{45}$ While $\S 409 \mathrm{~A}$ also addresses funding, ${ }^{46}$ for our purposes, it is sufficient to remember that nonqualified deferred compensation may represent only an unsecured promise to pay and that any funds backing up such a promise must also be available to a company's general creditors. Participants in plans that run afoul of $\S 409 \mathrm{~A}$ are subject to taxation of deferred amounts when they vest and an additional $20 \%$ penalty tax on the value of the deferred compensation. ${ }^{47}$

While $\S 409 \mathrm{~A}$ is daunting in some respects, the law had no impact on the underlying economics of nonqualified deferred compensation. ${ }^{48}$ Professor Halperin drew attention to the potential joint tax advantage of the nonqualified deferred compensation tax regime thirty years ago in his seminal Yale Law Journal article on taxation and the time value of money. ${ }^{49}$ As he demonstrated, the deferral of the employer's deduction to match the timing of employee inclusion is insufficient to eliminate the joint tax advantage of nonqualified deferred compensation. The net effect of the nonqualified deferred compensation taxation regime (assuming no change in tax rates ${ }^{50}$ ) is to tax investment returns during the period of deferral at the employer's rate rather than at the employee's rate. ${ }^{51}$ As Professors Halperin and Warren put it in a recent succinct analysis, nonqualified deferred compensation is tax advantaged under normal assumptions "if the employer earns an after-tax

${ }^{44}$ I.R.C. $\S 409 \mathrm{~A}(\mathrm{a})(4)$ (2012). There is an exception for newly hired employees. I.R.C. $\S 409 \mathrm{~A}(\mathrm{a})(4)(\mathrm{B})(\mathrm{ii})$. In general this requirement is not a change from prior law. Rev. Rul. 60-31, 1960-1 C.B. 174; see also Rev. Proc. 92-65, 1992-2 C.B. 428.

45 I.R.C. $\S 409 A(a)(2)(A)$. As Polsky notes, these distribution rules ensure that deferrals are essentially irrevocable. See Polsky, supra note 40, at 643.

46 I.R.C. $§ 409 \mathrm{~A}(\mathrm{~b})$.

47 I.R.C. $\$ 409 A(a)(1)$.

48 Eric D. Chason, Deferred Compensation Reform: Taxing the Fruit of the Tree in its Proper Season, 67 OHIO ST. L.J. 347, 349 (2006); Polsky, supra note 40, at 643.

${ }^{49}$ See Halperin, supra note 12 , at 540.

${ }^{50}$ Although generally difficult to predict, changes in tax rates affect the attractiveness of nonqualified deferred compensation. Specifically, nonqualified deferred compensation tends to be preferred over cash from a joint tax perspective if the employee's tax rate is expected to be lower at payout than at deferral (either because of a change in the brackets or one's position within the brackets) and/or if the employer's tax rate is expected to be higher at payout than at deferral. MYRON S. SCHOLES ET AL., TAXES AND Business STRATEGY: A PLANNING APPROACH 183 (2nd ed. 2001). Thus, while a reduction in the corporate tax rate from $35 \%$ to, say, $25 \%$ would generally increase the attractiveness of nonqualified deferred compensation in steady state, the prospect of such a reduction in the future might dampen appetites for deferred compensation plans today. Executives who expect to have less income and to face a lower marginal rate in retirement would tend to prefer deferred compensation, all else being equal.

51 See Halperin, supra note 12, at 539-41. See also Alvin C. Warren, Jr., The Timing of Taxes, 39 NAT'L TAX J. 499 (1986) (generalizing the underlying principle and discussing a number of applications). 
return on the deferred compensation that is higher than that available to the employee," 52 and this view is well accepted. ${ }^{53}$

As Halperin noted back in 1986, nonqualified deferred compensation arrangements will be tax advantaged if a plan sponsor is effectively tax exempt because of excess tax losses. ${ }^{54}$ He noted further that other nonqualified deferred compensation plan sponsors could invest in dividend paying stocks and exclude a large fraction of dividend income or could invest in their own stock and avoid tax on appreciation on those shares per $\S 1032.55$ Viewing these arrangements as providing an unintended and unwarranted subsidy for high-income taxpayers, Halperin proposed the adoption of a special tax, payable by employers, on the investment income generated by nonqualified deferred compensation arrangements, a tax that would replicate the economic impact of accrual taxation ${ }^{56}$

52 Halperin \& Warren (2014), supra note 32, at 329. Halperin \& Warren's example is reproduced in the Appendix. Other examples can be found in Halperin, supra note 12, at 519-20; Doran, supra note 12, at 6-7.

53 SCHOLES ET AL., supra note 50; Doran, supra note 12, at 1; Yale \& Polsky, supra note 12, at 576-78. But see Ethan Yale, Investment Risk and the Tax Benefit of Deferred Compensation, 62 TAX L. REv. 377, 377 (2009) (arguing that the conventional analysis fails to account for differences in investment risk within and without nonqualified plans).

This approach to analyzing the joint tax consequences of nonqualified deferred compensation, and conversely, the consequences for the public fisc, is essentially a "passthrough" approach. It assumes that plan sponsors are investing dollars on behalf of participants and sharing the tax burden in some fashion. There are other frames that may have different implications for the public fisc. For example, one could view nonqualified deferred compensation as a tax-advantaged substitute for equity investment. Normally, profits that are paid out of a company are double taxed - the corporate level tax is combined with a tax on dividends (with no corporate deduction for dividends paid) - but profits that are paid out as compensation are only taxed once - the corporate tax is combined with taxable (and deductible) compensation. The difficult question, which I must leave to future work, is whether or in what circumstances an "equity substitute" approach is more appropriate than a "pass-through" approach. This Article will embrace the pass-through approach that generally undergirds the previous work in this area highlighted in this section. I thank Dan Halperin for calling my attention to the "equity substitute" approach and discussing it with me.

${ }^{54}$ Halperin, supra note 12 , at 540. In 1986, non-governmental tax-exempt entities also could provide their employees with unlimited tax advantaged nonqualified deferred compensation (Halperin, supra note 12, at 540), but that situation is more complicated today. See infra note 180.

55 Halperin, supra note 12 , at 540 . At the time, corporations could deduct $85 \%$ of dividends received on small holdings of shares of other firms. Today, the general dividend received deduction is 70\%. I.R.C. § 243(a) (2012).

${ }^{56}$ Accrual taxation would require assessment and payment of tax on gains and losses annually, despite the absence of cash flows providing funds to pay the tax. 
and would level the (tax) playing field between current and deferred compensation. ${ }^{57}$

Professors Ethan Yale and Gregg Polsky have worked out the details of a special tax on nonqualified deferred compensation investment income at length. ${ }^{58}$ Yale and Halperin subsequently described the implementation of such a tax as feasible, but not easy. ${ }^{59}$ Professor Michael Doran has proposed application of accrual taxation to nonqualified deferred compensation, that is, taxation in the year in which compensation is earned, irrespective of the timing of payout, arguing that measurement and ability to pay issues are manageable. ${ }^{60}$ All of these commentators agree that $\S 409 \mathrm{~A}$ fails to address the fundamental lack of neutrality in the taxation of current compensation and nonqualified deferred compensation. ${ }^{61}$

In a recent working paper, Doran argues that a combination of tax advantages explains the motivation of firms to employ nonqualified deferred compensation at least as well as competing explanations. On the specific question of the joint tax advantage of retirement balances being invested by firms instead of by executives individually, Doran states that it is "commonplace" for companies to invest nonqualified defined contribution plan deferrals in their own stock, and that "this practice has a solid foundation in tax law," given the fact that firms are not taxed on gains on their own stock. ${ }^{62}$

\section{Nonqualified Deferred Compensation Accounting}

\footnotetext{
${ }^{57}$ Halperin, supra note 12, at 544 (suggesting a special tax on nonqualified deferred compensation investment income set at the top individual marginal rate).

The joint tax advantage identified by Halperin assumes that employee outside investment returns are taxed at regular individual rates. As discussed supra note 173 and accompanying text, individuals can reduce taxes on savings by investing through certain insurance products. Moreover, as the recent Panama Papers revelations starkly demonstrate, some wealthy U.S. citizens apparently have minimized or avoided tax on outside investment through the use of anonymous offshore accounts. Eric Lipton \& Julie Creswell, Panama Papers Show How Rich United States Clients Had Millions Abroad, N.Y. Times (June 5, 2015), http://www.nytimes.com/2016/06/06/us/panamapapers.html?hp\&action=click\&pgtype $=$ Homepage \&clickSource=story-

heading\&module=first-column-region\&region=top-news\&WT.nav=top-news\&_r=1.

58 Yale \& Polsky, supra note 12, at 599.

59 See Halperin \& Yale, supra note 12, at 939.

60 Doran, supra note 12 , at 15.

61 See Doran, supra note 12, at 1-2; Halperin \& Yale, supra note 12, at 941; Polsky, supra note 40, at 639-40; Yale \& Polsky, supra note 12, at 574.

62 Doran, supra note 11, at 28. Doran cites Jackson and Honigsberg for the proposition that firm investment of deferred amounts in company stock is commonplace, but Jackson and Honigsberg only investigated executive notional investment. Discussion of the taxation of COLI products, which are often used to informally fund note nonqualified deferred compensation arrangements, is deferred until Part III(C).
} 
Nonqualified deferred compensation obligations are reflected as liabilities on corporate balance sheets, and net income is adjusted in each period for increases or decreases in these liabilities (a process known as "marking to market"). ${ }^{63}$ DB liabilities may fluctuate somewhat with changes in interest rates, but are relatively stable. ${ }^{64}$ DC liabilities, on the other hand, can be highly volatile as a large fraction of participant balances are notionally invested in equity securities. ${ }^{65}$ Employers cannot formally fund these obligations without jeopardizing participant tax deferral, but liabilities can be informally funded by setting aside assets in a rabbi trust, a corporate owned life insurance (COLI) vehicle, or simply in a segregated account, as long as these funds remain available to general creditors. With one important exception, firms can hedge the income statement volatility (as well as the economic risk) that arises from participant notional investments in nonqualified DC plans by purchasing identical securities with the funds in the rabbi trust, COLI, or segregated account. The income statement effects of fluctuations in the deferred compensation liability and the hedge offset. 66

The important exception is company stock. Suppose that an executive notionally invests her nonqualified DC account balance in own-company stock. Assuming that the account balance will be paid in cash, gains and losses on that notional investment must be marked to market in each period as with any other nonqualified plan liability. ${ }^{67}$ Now assume that the company repurchases an equivalent number of shares in the market or sets aside an equivalent number of treasury shares, placing these shares in its rabbi trust, COLI, or segregated account. That hedge will be effective as an economic matter, but it will not offset the income statement impact of the liability. Gains or losses on shares of a company, held by that company, even if acquired to hedge obligations such as these, are not reflected on the income statement. 68 Income statement volatility associated with notional own-company stock investment can be approximately hedged using a closely

${ }^{63}$ Accounting Standards Codification 710-10-35-4 (Fin. Accounting Standards Bd.). This statement is true unless the deferral is in the form of company stock, is not diversifiable, and will be settled using company stock, in which case the obligation is treated as an equity instrument rather than as a liability. Emerging Issues Tax Force No. 97-14 (Fin. Accounting Standards Bd.) [hereinafter EITF No. 97-14].

${ }^{64}$ Lee Nunn, "Informal Funding" of NQDC Plans, in TAXATION AND Funding OF NonQuALIFIED DEFERRED COMPENSATION 205 (Marla J. Aspinwall and Michael G. Goldstein, eds., 2d ed. 2012). 65 Nunn, supra note 64, at 204.

${ }^{66}$ Nunn, supra note 64, at 200. Mark-to-market accounting for mutual funds held in segregated accounts to hedge plan liabilities is not automatic, but requires a sponsor election. ASC 825-10-25. See also Lee Nunn, Financial Accounting and NQDC, in TAXATION AND Funding OF NonQUALIFIED DEFERRED Compensation 296 (Marla J. Aspinwall and Michael G. Goldstein, eds., 2d ed. 2012). Mark-to-market accounting for COLI gains and losses is automatic. Accounting Standards Codification 325-30-35-2 (Fin. Accounting Standards Bd.); Nunn, supra note 64, at 204.

67 EITF No. 97-14, supra note 63.

${ }^{68}$ EITF No 97-14, supra note 63. See also MuldinTBG, An Overview to Deferral Plan Notional STOCK ACCOUNTING (2014). 
correlated security, such as an index, but cannot be perfectly hedged with owncompany stock. 69

This accounting problem arises whenever nonqualified deferred compensation is notionally invested in own-company stock but payable in cash or is payable in stock but diversifiable at some point into other investments. In either case, mark-to-market accounting of the liability is required and no perfect income statement hedge is available. On the other hand, if an executive defers company stock in kind, will receive stock in kind, and is not allowed to diversify, mark-tomarket accounting of the obligation is not required, and no income statement volatility arises. ${ }^{70}$

\section{E. Efficient Asset Allocation and Other Features of Nonqualified Deferred Compensation}

While the concerns of nonqualified DB plan participants are essentially limited to the security of their benefits, DC plan participants are also concerned about allocating their notional assets in such a way as to maximize the amount of their benefits while managing investment risks. The investment portfolio optimizing choices of participants may conflict with tax minimization goals and accounting concerns.

For example, experts suggest that individuals should invest a relatively large fraction of retirement savings in equity securities and a relatively small fraction in debt, particularly when an individual is far from retirement. ${ }^{71}$ But participant notional investment in equities results in greater earnings volatility and generally poorer joint tax consequences than notional investment in debt securities.

Moreover, while the nonqualified DC joint tax advantage is large when executives notionally invest in own-company stock and firms hedge with treasury shares, finance theory suggests that this practice would not be prevalent. Typically, executives are poorly diversified, with too much of their personal and financial capital invested in their firms. ${ }^{72}$ Of course, firms often compensate these under-

\footnotetext{
69 MullintBG, Benefit Trends Insights, Complementing Restricted Stock with a Deferred COMPENSATION Plan [hereinafter COMPLEMENTING RESTRICTED STOCK] (noting that the income statement impact of notional own-company stock investment cannot be adequately hedged with treasury shares).

${ }^{70}$ EITF No. 97-14, supra note 63; COMPLEMENTING RESTRICTED STOCK, supra note 69.

${ }^{71}$ Rules of thumb differ, but one way to get a sense of recommended asset allocations is to look at the composition of retirement target date funds. For example, Fidelity's Freedom Fund targeted at a 40-year-old individual anticipating retirement in 25 years allocates $90 \%$ of investments to equities, while the fund targeted at a 60-year-old anticipating retirement in 5 years still allocates $60 \%$ of investments to equities. See, e.g., Fidelity Freedom Funds, FIDELITY, https://www.fidelity.com/mutual-funds/fidelity-fund-portfolios/freedom-funds (last visited July 26, 2016).

72 Brian J. Hall, Six Challenges in Designing Equity-Based Pay, 15 J. ApPLIED CoRP. Fin. 21, 26
} 
diversified executives with equity to align incentives with shareholders, but shareholders pay a cost to induce executives to accept this risky, non-diversifying pay. ${ }^{73}$ It is one thing to ask executives to accept a grant of stock options, which might only partially replace other compensation; it is another to ask them to defer current pay into company stock. If given a choice between notional investments, few well-advised executives would select company stock absent additional inducements. ${ }^{74}$

Related lines of research have considered whether nonqualified deferred compensation, as an unsecured claim against corporate assets, might serve a corporate governance function in aligning executive incentives with those of debtholders, a question that gained increased urgency following the 2008 financial crisis, ${ }^{75}$ or whether nonqualified deferred compensation might be a means of camouflaging top executive compensation, in which case heavy use might be a symptom of managerial power. ${ }^{76}$ This research does not directly inform the tax analysis that is the focus of this Article, so I will not summarize it here, but will direct interested readers to the discussion provided in a recent article by Robert Jackson and Colleen Honigsberg, ${ }^{77}$ and will simply echo Jackson and Honigsberg's point that these two stories are not mutually exclusive, nor are they mutually

(2003).

${ }^{73}$ See Brian J. Hall \& Kevin J. Murphy, Stock Options for Undiversified Executives, 33 J. AccT AND ECON. 3, 6 (2002).

${ }^{74}$ Benartzi et al., The Law and Economics of Company Stock in 401(k) Plans, 50 J.L. \& Econ. 45, 50 (2007), estimate that qualified plan participant investments in own-company stock can be worth less than fifty cents on the dollar, depending on the investment horizon, fraction of assets invested in own-company stock, and volatility. To some degree, nonqualified deferred compensation balances notionally invested in company stock might satisfy executive share-holding requirements, in which case notional investment of nonqualified deferred compensation balances in own-company stock might not worsen an executive's aggregate diversification position.

75 This explanation for nonqualified deferred compensation would be consistent with an "optimal contracting" view of executive pay. In brief, the optimal contracting view posits that executive pay arrangements are selected to minimize managerial agency costs and maximize shareholder value. See David I. Walker, The Law and Economics of Executive Compensation: Theory and Evidence, in RESEARCH HANDBOOK ON THE ECONOMICS OF CORPORATE LAW 232, 234 (Claire A. Hill \& Brett H. McDonnell eds., 2012); John E. Core et al., Executive Equity Compensation and Incentives: A Survey, 9 ECoN. Policy REviEW 27, 27-28 (2003).

76 The managerial power view posits that executive pay arrangements reflect agency costs, as well as combat them, and that compensation design is not consistent with shareholder value maximization. Under this view, the threat or reality of investor and financial press outrage plays an important role in disciplining compensation, and, as a result, executives and directors seek out low salience channels of pay and other means of camouflaging compensation to minimize outrage. Lucian A. Bebchuk, Jesse M. Fried, \& David I. Walker, Managerial Power and Rent Extraction in the Design of Executive Compensation, 69 U. CHI. L. REV. 751, 789 (2002).

77 Jackson \& Honigsberg, supra note 39 , at 483-85. 
exclusive vis-a-vis potential tax motivations for nonqualified deferred compensation.

\section{Approach and Methodology}

Ideally, tax (and accounting ${ }^{78}$ ) rules would be neutral with respect to alternative compensation choices. Neutral rules avoid potentially inefficient distortions in pay practices as well as adverse distributional impacts. ${ }^{79}$ In the nonqualified deferred compensation realm, the ideal set of tax rules would ensure neutrality as between current and deferred compensation irrespective of notional investments made by executives, the uses to which firms put deferred amounts, and the tax rates faced by both parties. Commentators have proposed two means of achieving that neutrality: applying current or accrual taxation to nonqualified deferred compensation contributions and earnings ${ }^{80}$ and imposing a special, neutralizing tax on the investment income arising from nonqualified deferred compensation. ${ }^{81}$

Under an accrual-based scheme, nonqualified deferred compensation participants, or plan sponsors, would remit taxes based on contributions and annual gains or losses. ${ }^{82}$ This scheme would impose compliance costs on sponsors and/or participants and would require estimations and "truing-up" with respect to defined benefit plans, but accrual taxation of nonqualified deferred compensation appears to be administratively feasible. ${ }^{83}$ However, accrual taxation raises the specter of liquidity concerns inhibiting the use of nonqualified deferred compensation. ${ }^{84}$ Commentators have argued that these concerns are overblown, 85 and that is likely true, but applying accrual taxation to nonqualified deferred compensation, as a general matter, may be politically unacceptable, nonetheless. ${ }^{86}$

Under Halperin's proposal, employers would remit a special tax assessed (at the top individual marginal rate) on nonqualified deferred compensation

\footnotetext{
78 David I. Walker, Reconsidering Realization-Based Accounting for Equity Compensation 5-6. (Boston Univ. Sch. of Law, Law \& Econ. Working Paper No. 16-03, Jan. 14, 2016), available at http://ssrn.com/abstract=2715624 (arguing for mark-to-market accounting for long-term equity pay in order to level the accounting playing field between competing instruments).

${ }^{79}$ Halperin, supra note 12, at 539 (1986) (arguing that the NQDC joint tax advantage could create an unwarranted subsidy for high income taxpayers).

80 See Doran, supra note 12 , at 2.

81 Halperin, supra note 12, at 14-15; Yale \& Polsky, supra note 12, at 574; Halperin \& Yale, supra note 12 , at 943.

82 Doran, supra note 12 , at $5,15$.

83 Doran, supra note 12 , at 15-16.

${ }^{84}$ Halperin \& Yale, supra note 12, at 940.

85 Doran, supra note 12, at 16; Halperin, supra note 12, at 541; Halperin \& Yale, supra note 12, at 940 ; Yale \& Polsky at 632-33.

${ }^{86}$ Halperin \& Yale, supra note 12, at 940; Yale \& Polsky at 633.
} 
investment returns, while leaving the other tax rules applicable to nonqualified deferred compensation in place. ${ }^{87}$ This approach allays liquidity concerns, and, in concept, yields an overall result that is economically equivalent to accrual taxation. ${ }^{88}$ However, as Yale and Polsky argue, there would be tradeoffs between the accuracy and administrability of a special tax regime. ${ }^{89}$ This is not to suggest that the obstacles to accrual taxation or the imposition of a special tax are insurmountable, only that leveling the tax playing field in this area may not be as simple or as feasible as one might hope. ${ }^{90}$

At the same time, one can question whether a lack of tax neutrality in this realm presents a serious problem in terms of compensation distortion, high-income taxpayer subsidy, or adverse impact on the public fisc. To be sure, employers facing low effective marginal tax rates and their executives can generate significant joint tax advantages on deferred compensation. But at current tax rates, deferred compensation plans sponsored by firms with positive tax liabilities can generate joint tax consequences ranging from disadvantage to advantage, depending on notional investments by participants and uses of deferred amounts by employers. Including the $3.8 \%$ net investment income surtax ${ }^{91}$ and an estimated $1.2 \%$ point effective marginal rate impact of the itemized deduction phase out, ${ }^{92}$ top individual marginal federal tax rates total $25 \%$ on long-term capital gains and dividends, and $44.6 \%$ on interest and short-term capital gains. The top corporate rate of $35 \%$ applies to capital gain (except for gains on own-company stock), interest, and business profits. ${ }^{93}$ Most dividends on shares of other companies are effectively taxed to corporate recipients at a $10.5 \%$ rate once the dividend-received deduction is factored in. And firms pay no tax on gains on their own stock per $\S 1032 .{ }^{94}$

\footnotetext{
${ }^{87}$ Halperin, supra note 12 , at 544-50.

88 Halperin, supra note 12 , at 544-50.

89 Yale and Polsky, supra note 12, at 574, passim (analyzing the implications of, inter alia, choices with respect to the party remitting the special tax and the timing of remittance).

90 Polsky, supra note 40, at 640 (noting that "neutralization would be somewhat complex"); Halperin \& Yale, supra note 12, at 939.

${ }^{91}$ I.R.C. $§ 1411(\mathrm{a})(1)$ (2012).

92 Alan D. Viard, The Basic Economics of Pease and PEP, 146 TAX NoTES 805, 808 (Feb. 9, 2015) (reporting Tax Policy Center estimate of the impact of the itemized deduction phase out for taxpayers with cash income in excess of $\$ 1$ million for 2013).

93 The effective marginal rate faced by businesses eligible for the $\S 199$ Production Activities Deduction is reduced by 3.15 percentage points. Molly F. SHERlock, Cong. RESEARCH SERV., RL41988, The SECTION 199 PRoduction ACTIVITIES DEDUCTION: BACKGROUND AND ANALYSis (Feb. 27, 2012).

${ }^{94}$ The joint tax analysis is also impacted by differences in state and local income tax rates applicable to investments made by individual and corporate taxpayers. Because these rates vary widely, I follow previous commentators in ignoring sub-Federal taxes in my joint tax analysis.

It seems likely that there will be changes in both corporate and individual rates under the Trump administration, but the impact on the joint tax consequences of nonqualified deferred compensation is unclear. The Trump campaign proposed a maximum rate of $20 \%$
} 
Firms and executives may be operating nonqualified deferred compensation plans in such a way as to generate joint tax advantages, or they may not. Various frictions may prevent firms and executives from doing so. As we have seen, accounting rules may conflict with tax-optimizing behavior, and participants seeking to optimize their investment portfolios may desire to notionally invest nonqualified DC amounts in ways that are not conducive to minimizing the joint tax bill. There are, in short, tensions between the various objectives of participants, plan sponsors, and shareholders.

How these tensions are resolved is an empirical question. But given the difficulties (political or otherwise) of achieving tax neutrality, it is worth investigating how nonqualified deferred compensation plans are operated in practice to determine whether or to what extent frictions or other considerations deter firms and executives from minimizing taxes associated with nonqualified deferred compensation. Is achieving tax neutrality worth it?95

Currently, firms are not required to disclose the notional nonqualified defined contribution investments of senior executives or other plan participants; ${ }^{96}$ nor are they required to disclose how deferred amounts arising from DB or DC programs are used. These decisions are almost totally opaque. Firms are required to disclose annual returns on nonqualified DC balances for their "top 5" executives, and in recent work, Jackson and Honigsberg utilized this data to reach inferences regarding executive notional investment. ${ }^{97}$

The strategy employed in this paper is different. I interviewed ten individuals at eight firms with extensive experience in the nonqualified deferred

on capital gains and dividends received by individuals and a maximum corporate rate of 15\%. Jim Nunns et al., An Analysis of Donald Trump's Tax Plan, URBAn InSTITUTE \& BRookingS Institution TAX Policy Center (Dec. 22, 2015), http://www.taxpolicycenter.org/publications/analysis-donald-trumps-tax-plan/full. In 2016 , House Republicans proposed a maximum corporate rate of $20 \%$ and a top rate of $16.5 \%$ on individual receipt of interest, dividends, and capital gains. Kyle Pomerleau, Details and Analysis of the 2016 House Republican Tax Reform Plan, TAX Foundation (July 5, 2016), http://taxfoundation.org/article/details-and-analysis-2016-house-republican-taxreform-plan.

95 Yale and Polsky, supra note 12, at 589 (2007) ask whether revising nonqualified deferred compensation taxation is worth it, but they focus on the possibility of firms shifting to other tax-advantaged compensation instruments, such as equity pay, if the nonqualified deferred compensation opportunity is eliminated. This is a valid question, but I am asking whether nonqualified deferred compensation tax reform is "worth it" from a different perspective. Given frictions and other considerations, does the current regime result in substantial adverse consequences?

96 Jackson \& Honigsberg, supra note 39 , at 507-08, propose mandatory disclosure of senior executive notional nonqualified deferred compensation investments.

${ }^{97}$ See infra note 121. 
compensation "space." These individuals include consultants that advise companies with respect to the adoption and design of nonqualified deferred compensation plans, and individuals employed by firms engaged in administering nonqualified deferred compensation plans. ${ }^{98}$ These individuals have access to information that is not publicly available. I also consulted surveys conducted by nonqualified deferred compensation administrators, Newport Group and MullinTBG, and other public sources. However, as discussed below, I was cautioned that survey responses are not random and that while the survey information is quite helpful, some of the data is likely to be affected by a response bias.

The interviews were open-ended telephonic discussions that focused on factual, often numeric questions, such as "what fraction of your clients informally fund nonqualified deferred compensation obligations," although sources very generously took the time to explain motivations, e.g., why accounting rules encourage funding in certain situations. While there was some variation in views among these sources, perhaps reflecting differences in client bases or experience, these individuals painted a reasonably consistent picture of nonqualified deferred compensation programs as they currently operate in practice. ${ }^{99}$

The interview and survey evidence was supplemented with hand-collected data gleaned from the proxy statements and nonqualified defined contribution deferred compensation plan documents of a small sample of S\&P 500 companies. These documents shed considerable light on the range of what is permissible within nonqualified deferred compensation plans, but only limited light on actual practices. ${ }^{100}$

\footnotetext{
98 Interviewees included individuals employed by the large, well-known executive benefit consultancies including Ernst \& Young, Mercer, and Willis Towers Watson; and by smaller consulting and/or plan administration firms Lockton, MullinTBG, Newport Group and October Three. Some sources had experience in both plan administration and plan design. Some sources preferred that their names and company affiliations not be disclosed and are referenced accordingly.

Interviewees were identified in several ways. Some individuals were listed as contacts on whitepapers or client memos issued by their firms that addressed various nonqualified deferred compensation topics. Others were identified through referrals within the various organizations.

${ }^{99}$ While the interview evidence must be classified as anecdotal, I gained confidence in the information I received as a result of internal coherence, consistency with survey evidence and proxy statement disclosures (when available), and consistency with theory.

100 I began with a random sample of 50 S\&P 500 companies. Proxy statement disclosures indicate the 40 of these companies have an active nonqualified DC deferred compensation program. Of course, proxy statement disclosures pertain only to the most senior "named executive officers" (NEOs) of a company. It is possible that some of these firms operate nonqualified programs that are not open to their NEOs, but this seems unlikely. Data reported on usage of the identified nonqualified programs is necessarily limited to usage by the NEOs.
} 


\section{Nonqualified Deferred Compensation in Practice}

This Part describes evidence from surveys, interviews, and company filings that bears on notional investments by nonqualified DC plan participants and plan sponsor use of funds freed up as a result of the decision to defer compensation. Both are critical factors in determining the joint tax consequences of nonqualified plans as they operate in practice, as detailed in the final section of this Part.

\section{A. Participation and Source of Funds}

While plan details vary, most nonqualified DC plans involve elective deferrals by participants of a fraction of salary, annual bonus, and sometimes other compensation. ${ }^{101}$ But employer contributions to nonqualified DC plans are common, as well. Fifty percent of firms responding to the Newport Group survey that maintain nonqualified DC plans reported that they make company contributions to these plans. ${ }^{102}$ Sources generally agreed, however, that participant elective deferrals make up well over $50 \%$ of total nonqualified DC plan contributions. ${ }^{103}$ of course, the nominal source of funds does not establish which party bears the burden, but the nominal source of funds may be important when it comes to the notional investment of these funds. Some plans place vesting or investment allocation restrictions on "company" funds that do not apply to "participant" contributions.

${ }^{101}$ E.g., Newport Group Survey, supra note 37, at 23 (indicating that 93\% of responding companies allow participants to defer some or all of their base salary and annual bonus and that most of these firms allowed participants to defer $75 \%$ or more of these sources of income). Six percent of the firms responding to the Newport Group's survey indicated that participants are permitted to defer restricted stock and restricted stock units. $I d$.

102 Newport Group Survey, supra note 37, at 15. An executive who makes elective nonqualified DC plan deferrals will often face a reduction in company matching funds under her firm's qualified 401(k) plan. "Make-up" contributions to the executive's nonqualified DC plan make the executive whole with respect to the reduction. This is the most common company approach, but some firms make discretionary contributions to nonqualified DC plans, and some firms match participant contributions as if the 401(k) plan had no ceiling on contributions. Newport Group Survey, supra note 37, at 15.

103 Telephone Interview with Douglas B. Frederick, Partner, and Kevin L. Mitchell, Principal, Mercer [hereinafter Frederick \& Mitchell Interview] (Feb. 29, 2016); Telephone Interview with Michael D. Shannon, Vice President, Non-Qualified Consulting, Newport Group [hereinafter Shannon Interview] (Feb. 23, 2016) (estimating that, depending on economic conditions, $80 \%$ of the contributions in nonqualified DC plans come from participants); Telephone Interview with Senior Vice President of Executive Benefits Consulting and Design Firm [hereinafter Interview with Senior VP of Executive Benefits Consulting and Design Firm] (Feb. 19, 2016) (estimating that 90\% of contributions are from participants); Telephone Interview with Executive Benefits Consultants with an International Firm, supra note 39. For my sample of S\&P 500 firms, $73 \%$ of the contributions in the most recent year consisted of employee dollars. 
Nonqualified DC plans are generally open to executives and employees beyond the senior executive suite. Eligibility is generally determined by position (most commonly senior vice presidents or above) or by compensation level (most commonly in the $\$ 115,000-\$ 150,000$ range or above). ${ }^{104}$ Respondents to the Newport Group survey reported that about $46 \%$ of eligible individuals elected to defer compensation in 2013. ${ }^{105}$

Nonqualified DB plans are commonly structured as supplemental executive retirement plans. Participation is defined by contract, and the plan sponsor generally makes all contributions.

\section{B. Participant Notional Investment}

DB plans are typically designed to replace a fraction of participants' preretirement income. 106 The plan sponsor is responsible for ensuring that funds will be available to provide benefits, and participants are not involved in these decisions. There is no notional investment in own-company stock, or any other notional investment for that matter, in these DB plans.

DC plans generally shift the investment responsibility, at lease notionally, to participants. Companies are still responsible for ensuring that funds are available to provide benefits (recall that the benefit reflects an unsecured promise to pay), but the level of promised benefits is determined by participant notional investment choices, not by a pre-determined formula.

Typically, participants are offered a range of notional investment options that is the same as or similar to the range of investments offered in a firm's $401(\mathrm{k})$ program. Two-thirds of the firms responding to the Newport Group survey that offered mutual fund investments reported that their plans included ten to nineteen investment options.107 One source suggested that the idea is to cover all of the major investment categories, while minimizing duplication. ${ }^{108}$

104 Newport Group Survey, supra note 37, at 18-19.

105 Newport Group Survey, supra note 37, at 21.

106 Newport Group Survey, supra note 37, at 42.

107 Newport Group Survey, supra note 37, at 24. Forty percent of a sample of S\&P 500 firms that offer nonqualified DC plans disclosed in proxy materials or plan documents that the notional investment options were the same as or similar to their 401(k) investment options, but about half of firms failed to make any disclosures on this issue.

An obscure, but possibly important reason for mirroring 401(k) investment menus is qualification of nonqualified DC benefits as "retirement income" under a federal statute that bars states from taxing retirement income received by out-of-state residents. 4 U.S.C. $\S$ 114 (1996). For example, suppose that an executive works in New York (a high tax state) and subsequently retires to Florida (a no tax state). Under regular tax principles, New York would have grounds for taxing retirement income earned in New York although received in Florida. 4 U.S.C. $\S 114$ bars such out-of-state taxation, but only to the extent of "retirement income," a defined term. Retirement income includes nonqualified DC benefits that are 
Survey and interview responses indicate that a minority of firms allow participants to notionally invest in own-company stock. Only $21 \%$ of the firms responding to the Newport Group's survey reported that company stock was a permissible investment option. ${ }^{109}$ Interview sources confirmed that most firms do not include own-company stock as a notional investment option. ${ }^{110}$

Sources agreed that a primary reason many companies exclude owncompany stock from their notional investment menus is the difficulty of managing income statement volatility associated with this investment choice. ${ }^{111}$ But other

received in the form of a ten-year or longer annuity, but lump sum payments are considered retirement income only if the DC program exists "solely" to supplement a tax-limited qualified plan. Although the law on this point has not been clarified, firms may think it prudent to mimic $401(\mathrm{k})$ terms as closely as possible in order to qualify lump sum nonqualified deferred compensation payouts as retirement income that is insulated from out-of-state taxation.

108 Interview with Executive Benefits Consultants with an International Firm, supra note 39. Sources noted that some plans limit investment choices with respect to unvested employer contributions, e.g., to fixed income investments only. Telephone Interview with Eric Kaufman, Senior Vice President, Lockton Companies (Feb. 16, 2016); Shannon Interview, supra note 103.

While one might expect highly compensated corporate executives to gravitate towards hedge funds and other aggressive investment alternatives, I have no evidence of these alternatives being offered through nonqualified deferred compensation arrangements.

${ }^{109}$ Newport Group Survey, supra note 37, at 26. Only 6.5\% of firms responding to a survey conducted by nonqualified deferred compensation plan administrator MullinTBG reported company stock as an investment option, but this fraction seems too low to be plausible. I do not have the survey questionnaire, but perhaps there was confusion between offering company stock as one option or as the sole vehicle. MULLINTBG, 2014 EXECUTIVE BENEFIT SURVEY, SUMMARY OF RESULTS 7 (2015) [hereinafter MullinTBG Survey].

110 Telephone Interview with Peter Neuwirth, Senior Consultant, Willis Towers Watson [hereinafter Neuwirth Interview] (Feb. 19, 2016); Interview with Executive Benefits Consultants with an International Firm, supra note 39; Shannon Interview, supra note 103; Interview with Senior VP of Executive Benefits Consulting and Design Firm, supra note 103. See also Chenyang Wei \& David Yermack, Investor Reactions to CEOs' Inside Debt Incentives, 24 REV. Fin. STUDIES 3813, 3823 (2011) (finding that 38\% of a sample of large companies in which CEOs had positive nonqualified deferred compensation balances prohibited notional investment in own-company stock); Frederick Tung \& Xue Wang, Bank CEOs, Inside Debt Compensation, and the Global Financial Crisis 53 (Boston Univ. Sch. of Law, Working Paper No. 11-49, 2012) (reviewing proxy statements for 83 banking companies and finding that 28 allowed senior executives to notionally invest in own-company stock, that 27 did not provide this option, and that another 27 did not offer nonqualified deferred compensation or had CEOs with a zero balance). Eleven of the forty S\&P 500 companies I analyzed allow participants to direct their contributions into company stock; eight did not allow this; the rest were silent on this issue.

${ }^{111}$ Newport Group Survey, supra note 37, at 26; Interview with Executive Benefits Consultants with an International Firm, supra note 39; Shannon Interview, supra note 103; Interview with Senior VP of Executive Benefits Consulting and Design Firm, supra note 103. 
reasons were offered as well. ${ }^{112}$ Notional nonqualified deferred compensation investment in own-company stock held by directors and officers is treated like other company shares held by these individuals for purposes of proxy disclosure; Securities Exchange Act (SEA) § 16 reporting requirements and short-swing trading restraints under SEA §16(b); and Sarbanes-Oxley limitations, including trading restrictions during qualified plan blackout periods. ${ }^{113}$

Some companies, however, allow or even encourage notional DC investment in own-company stock. Six percent of the companies responding to the Newport Group's survey indicated that participants are permitted to defer restricted stock or restricted stock units. Typically, these deferrals would be in and remain in the form of shares, avoiding the accounting problems associated with diversifiable or cash settled balances tied to own-company stock.114 More generally, one source indicated that about $10 \%$ of his clients require nonqualified DC investment to be in own-company stock. 115

In my sample of S\&P 500 nonqualified DC programs, no companies limited participant contributions to own company stock, but three companies tied employer contributions to their stock prices, 116 and two companies provided significant incentives for participants to notionally invest in own-company stock. Leggett \& Platt provides a $20 \%$ bonus for deferred amounts notionally invested in company stock. ${ }^{117}$ Aetna offers only two choices for investment - a company stock fund and a fixed income fund.118 But such cases seem rare. Much more common are

112 In addition to the obstacles that follow, MullinTBG notes that in some states owncompany shares held in a rabbi trust count towards dilution in addition to the notional own-company shares held in participant DC portfolios, doubling the dilutive impact of hedging own-company stock in kind. MULLINTBG, AN OVERviEW To DEFERral Plan NOTIONAL STOCK ACCOUNTING (2014).

11315 U.S.C. § 78p (2012); 15 U.S.C. § 7244 (2012); COMPLEMENTING RESTRICTED STOCK, supra note 69; Andrew C. Liazos, Sarbanes-Oxley Act - Implications for Executive Compensation, MCDERmotT, Will \& EMORY (Sep. 9, 2002); Frederick \& Mitchell Interview, supra note 103; Shannon Interview, supra note 103; Interview with Senior VP of Executive Benefits Consulting and Design Firm, supra note 103.

114 Newport Group Survey, supra note 37, at 23; Shannon interview, supra note 103. Thirty percent of the S\&P 500 companies I analyzed permitted RS/RSU deferrals, although senior executives took advantage of this opportunity at only 3 or 4 of the 40 firms.

115 Neuwirth Interview, supra note 110.

116 These companies are The Home Depot, J.M. Smucker, and PPG Industries. THE Home Depot, Proxy Statement and Notice of 2016 Annual MEeting of Shareholders 38 (Mar. 24, 2016); The J.M. SMucker Company, Proxy Statement AND Notice of 2015 AnNuAl MEeting of SHAREHOldERS 48-49 (Jul. 1, 2015); PPG IndUSTRIES, InC., DEFERRED COMPENSATION PlAn 14 (as amended and restated effective Jan. 1, 2011) (Exhibit 10.11 to Form 10-K filed Feb. 18, 2016).

117 Leggett \& Platt, Inc., Proxy Statement and Notice of 2016 Annual Meeting of SHAREHOLDERS 26 (Mar. 30, 2016).

118 Aetna, Inc., Proxy Statement and Notice of Annual Meeting of Shareholders of Aetna, INC. 49 (April 8, 2016). 
nonqualified DC plans that mirror 401(k)s and provide no apparent incentive for investment in own-company stock.

So how do nonqualified DC participants actually (notionally) invest? Surveys and proxy statement disclosures do not reach this question, but interview sources agreed on the general picture. Consistent with their diversification needs, participants generally do not voluntarily invest deferred cash compensation in owncompany stock. Some sources simply noted that they generally do not see executives investing in their own companies' stock. ${ }^{119}$ Another indicated that participants do so only when required to do so. ${ }^{120}$

Most sources declined to estimate the fraction of nonqualified DC funds notionally invested in own-company stock, preferring to focus on the limited opportunity to do so, but one source suggested that less than $20 \%$ of fund balances were notionally invested in own-company stock among their clients, in aggregate. ${ }^{121}$

119 Telephone Interview with John Lowell, Consultant, October Three [hereinafter Lowell Interview] (Feb. 16, 2016); Interview with Executive Benefits Consultants with an International Firm, supra note 39.

${ }^{120}$ Neuwirth Interview, supra note 110.

121 Frederick \& Mitchell Interview, supra note 103.

While consistent with diversification pressures and limited access to investment in own-company stock, the relatively modest notional investment in own-company stock by nonqualified DC plan participants described by sources appears to run counter to findings in recent work by Jackson and Honigsberg. See Jackson \& Honigsberg, supra note 39, at 496. Jackson and Honigsberg were interested in whether executive retirement account balances were notionally invested so as to align executive incentives with debtholders, as some had theorized. Jackson and Honigsberg argued that to the extent that retirement balances were notionally invested in own-company stock, they tended to align executives with shareholders, rather than with debtholders. Because notional retirement plan investments are not disclosed, Jackson and Honigsberg looked for a correlation between defined contribution plan returns, which are disclosed for "top 5" executives, and company stock returns. Jackson and Honigsberg noted that this approach has limitations, but they found evidence suggesting that "the value of a large proportion of executive retirement pay is linked to company stock prices," and that "the retirement benefits of more than one out of three executives are invested entirely in [their] company's stock." Jackson \& Honigsberg, supra note 39 , at 481 . Although I cannot readily identify the source of the discrepancy, one factor that might contribute is that proxy statement disclosures of nonqualified deferred compensation include vested, but undelivered restricted stock and performance shares, even if these shares are deferred for only two or three years. In my sample of S\&P 500 companies, short-term deferrals at two banks - Goldman Sachs and Morgan Stanley accounted for almost $70 \%$ of aggregate contributions to nonqualified deferred compensation accounts as disclosed in proxy statements.

To be clear, Jackson and Honigsberg were only interested in notional investment of account balances and the impact on the incentives of the executives holding these balances. They were not interested in what companies did with the deferred compensation amounts prior to payout. The latter question, as we will see, is of greater importance in determining the joint tax consequences of nonqualified deferred compensation. 
Moving beyond own-company stock, one source suggested that participants generally select notional investments in an economically rational manner, with a greater emphasis on equities during early earning years, shifting to more debt as participants near retirement. ${ }^{122}$ Other sources suggested that balances were typically notionally invested somewhat more conservatively than $401(\mathrm{k})$ balances. ${ }^{123}$ One source explained that because nonqualified deferred compensation is an unsecured promise to pay, participants were advised to draw down these funds before drawing on secured qualified plan funds, leading to a shorter investment horizon and a more conservative investment strategy. ${ }^{124}$ Another source noted that some participants use nonqualified elective deferral plans as a means of saving for their children's college education, rather than for retirement, again suggesting a shorter horizon and a more conservative investment approach. ${ }^{125}$ Again, most sources declined to estimate the typical investment portfolio, but one source suggested a ballpark estimate for aggregate defined contribution balances at large firms of $40 \%$ debt/10\% own-company stock/50\% other equities. ${ }^{126}$

\section{Informal Funding By Plan Sponsors}

Companies sponsoring nonqualified plans face three decisions in the interim between deferral and payout: 1) to what extent to set aside or informally fund obligations versus using deferred amounts in the business and operating the plan on a pay-as-you-go basis, and if funds are set aside, 2) what vehicles to use to manage these funds, if any, and 3) how to invest those funds.

Extent of Informal Funding. Firms cannot formally fund nonqualified plan obligations as they would qualified plan obligations without jeopardizing participant tax deferral. But firms can, and often do, informally set aside funds that offset nonqualified plan obligations. The first decision is whether to set aside funds or leave those funds in the business, reduce borrowing, etc. Sources and surveys provide several rationales for informal funding. First, income statement volatility arising from plan obligations (company stock excepted) can be managed by setting aside funds and purchasing identical securities. ${ }^{127}$ Second, ratings agencies and

\footnotetext{
122 Interview with Executive Benefits Consultants with an International Firm, supra note 39.

${ }^{123}$ Frederick \& Mitchell Interview, supra note 103.

${ }^{124}$ Frederick \& Mitchell Interview, supra note 103. Johnson \& Honigsberg's study confirms executives do tend to heed this advice. See Jackson \& Honigsberg, supra note 39, at 501 (finding that the median executive in their sample receives all retirement pay within three years of their separation from the company).

125 Neuwirth Interview, supra note 110.

126 Frederick \& Mitchell interview, supra note 103.

127 Newport Group Survey, supra note 37, at 50; MullinTBG Survey, supra note 109, at 9; Neuwirth Interview, supra note 110; Interview with Executive Benefits Consultants with an International Firm, supra note 39.
} 
analysts may be uncomfortable with large, unfunded plan liabilities on company balance sheets. ${ }^{128}$ Third, informal funding may, in fact, provide added security for plan participants in the event of bankruptcy or insolvency. One source recounted as conventional wisdom that while funds set aside in a rabbi trust technically are available to general creditors, the existence of such a trust tends to result in plan participants receiving a larger share of assets in bankruptcy or insolvency proceedings. ${ }^{129}$

On the other hand, large companies with relatively small nonqualified plan obligations may feel little need to set aside funds, while other firms may prefer to use the deferred compensation amounts in the business. ${ }^{130}$

Practitioner Robert Miller, writing in 2002, reported that it was most common not to informally fund nonqualified plans, ${ }^{131}$ but the situation apparently has changed. Sixty-two percent of the firms responding to the MullinTBG survey reported that they informally funded nonqualified plan obligations, while $71 \%$ of the Newport Group's respondents reported funding nonqualified DC obligations and $55 \%$ reported funding nonqualified DB obligations. ${ }^{132}$ One source cautioned that these surveys may overstate the prevalence of funding, ${ }^{133}$ but interviewee estimates were not materially different, ranging from $50 \%$ to $80-90 \%$ of firms informally funding nonqualified plan obligations to some degree. ${ }^{134}$

128 MullinTBG Survey, supra note 109, at 9; Interview with Senior VP of Executive Benefits Consulting and Design Firm, supra note 103.

${ }^{129}$ Neuwirth Interview, supra note 110. See also Complementing Restricted STOCK 3 (reporting that "there is anecdotal experience that an informally funded [nonqualified deferred compensation] arrangement does have some increased likelihood of successfully navigating the dangers of company insolvency"); M BENEFIT SOlUTIONS, WHITE PAPER: WHY COMPANIES USE RABBI TRUSTS 4 ("M Benefit Solutions has had several clients go through a bankruptcy and the existence of a rabbi trust, we believe, helped executives there to obtain payment of all or a large percentage of their nonqualified deferred compensation benefits. Whether they would have been able to obtain this result without an asset already set aside to make the benefit payments is difficult to say, but is less likely.").

To be sure, some of the sources of this anecdotal evidence have a financial interest in firms adopting rabbi trusts or other informal funding vehicles, but increased protection against insolvency risk would run counter to the nonqualified deferred compensation bargain.

130 MullinTBG Survey, supra note 109, at 9; Newport Group Survey, supra note 37, at 52; Lowell interview, supra note 119; Interview with Executive Benefits Consultants with an International Firm, supra note 39.

131 MILLER, supra note 34, at 284.

132 MullinTBG Survey, supra note 109, at 9; Newport Group Survey, supra note 37, at 51.

133 Lowell Interview, supra note 119. The concern is that the firms conducting the surveys are providers of funding vehicles, such as COLI, and that clients of these firms may respond at a higher rate than firms without a client relationship.

134 The estimates I received were as follows: 50-65\% (Frederick and Mitchell Interview, supra note 103), 55\% (Neuwirth Interview, supra note 110), 65\% (Interview with Executive Benefits Consultants with an International Firm, supra note 39), 75-90\% (Lowell Interview, 
Informal funding is not an all or nothing decision. Less than half of the firms responding to MullinTBG's survey reported funding $100 \%$ of liabilities. ${ }^{135}$ One source indicated that some of his clients fund only the equity portion of the DC notional investment portfolios of participants. Liabilities tied to debt securities are less volatile, and some firms see less of a need to hedge these liabilities. ${ }^{136}$

Informal Funding Vehicles. Firms that informally fund nonqualified plan obligations must choose a vehicle or vehicles to do so. The options are essentially rabbi trusts, corporate owned life insurance policies, and segregated accounts, although these can be and often are combined.

Rabbi trusts are very common. ${ }^{137}$ A rabbi trust is a grantor trust, and typically these trusts are designed to be irrevocable, providing plan participants with protection against an employer's change of heart or a possible change of control. ${ }^{138}$ But, as noted, trust assets are available to general corporate creditors. Income earned within rabbi trusts is taxed to the employer, and thus holding set aside funds in a rabbi trust (versus in a non-trust segregated account) has no tax consequences. ${ }^{139}$ Rabbi trusts are frequently used because they are simple and inexpensive to implement, because they provide a platform for hedging activities, and because, despite the requirement that trust assets remain available to general creditors, in practice they may provide some participant security, as explained above. ${ }^{140}$

Formerly, employers sometimes held set aside funds in offshore trust accounts as a means of increasing participant security. However, I.R.C. $§ 409 A(b)$ now provides for current participant taxation with respect to assets set aside in a foreign trust to informally fund nonqualified deferred compensation obligations, unless substantially all participant services are performed in the foreign jurisdiction. Presumably, substantially all rabbi trusts backing U.S. employmentbased nonqualified deferred compensation are located in the U.S.

supra note 119), 80-90\% (Interview with Executive Benefits Consultants with an International Firm, supra note 39).

135 MullinTBG Survey, supra note 109, at 9.

136 Neuwirth Interview, supra note 110.

137 Newport Group Survey, supra note 37, at 54 (88\% of DC plans with informal funding and $71 \%$ of DB plans with informal funding utilized rabbi trusts in 2013). But note that these figures may be overestimated because of the likely survey response bias discussed supra note 133.

138 The term "rabbi trust" reflects the historical accident that the first IRS letter ruling on these vehicles addressed a trust created by a congregation for the benefit of its rabbi. The IRS has provided a model rabbi trust document that serves as a safe harbor for these arrangements and specifies the basic terms. Rev. Proc. 92-64, 1992-2 CB. 22.

139 Grantor trust tax rules are found in I.R.C. $\S \S 671-679$ (2012).

140 See text accompanying supra notes 66, 129. 
Corporate-owned life insurance is commonly employed as a means of informally funding and sometimes managing nonqualified deferred compensation arrangements. COLI insures the lives of current and former employees, ${ }^{141}$ but the policies are owned by plan sponsors who pay the premiums and are the beneficiaries. A COLI policy is a general corporate asset, although a policy may be held within a rabbi trust, providing limited security to plan participants as discussed above. Alternatively, employers can use COLI products to manage set-aside assets and hedge participant notional investments without the necessity of creating a rabbi trust. ${ }^{142}$ Either way, employers typically purchase variable universal life insurance policies that allow them to select a mix of investments that match participant notional investment portfolios and to adjust these investments over time. ${ }^{143}$

COLI products provide certain tax benefits. Although premiums are not deductible, ${ }^{144}$ tax is deferred on the cash value buildup while a policy is in force, allowing plan sponsors to rebalance their hedging portfolios without incurring current tax; and death benefits, including both the pure insurance payout and investment returns, are received tax free if certain IRS requirements are met. ${ }^{145}$ In the not uncommon case in which a policy is liquidated prior to the death of an

${ }^{141}$ Although the cases are not uniform, employers have been held to have an insurable interest in the lives of their employees under state law, and that interest extends beyond the termination of their employment. Social security system data is used to determine when death benefits are due with respect to former employees. See Robert E. KEETON ET AL,

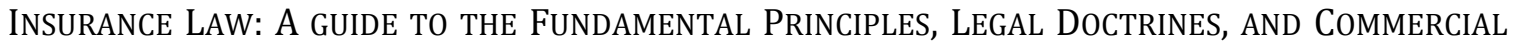
PRACTICES 158 (2d ed. 1988) (noting that some "courts have ... upheld COLI programs, at least when the employee consented to the placement of the life insurance on the employee's life and the employer made a colorable claim of financial loss resulting from the death of the employee"). Moreover, statutes have been enacted in some states explicitly recognizing that employers may have insurable interests in the lives of employees. See StEven PlitT ET AL, COUCH ON INSURANCE 3D, § 43:14 (2009) (citing Indiana Code § 27-1-12-17-1 as an example). 142 Interview with Senior VP of Executive Benefits Consulting and Design Firm, supra note 103.

143 Frequently Asked Questions about Coli, BoliColi.com, http://www.bolicoli.com/frequently-asked-questions-about-coli.

${ }^{144}$ I.R.C. § 264(a)(1) (2012) disallows deductions for insurance premiums when the taxpayer is the beneficiary.

145 Nunn, supra note 64, at 201 (citing I.R.C. §§ 101(j), 72(e)(5)(A), (e)(10) (2012)); Nonqualified Plan Basics, WELLS FARGO (2013), available at https://www08.wellsfargomedia.com/assets/pdf/commercial/retirement-employeebenefits/perspectives/nonqualified-plan-basics.pdf. Death benefits are taxable if a corporate owner fails to comply with IRC $\S 101(\mathrm{j})$. See infra note 178. Note also that COLI use can also result in increased Alternative Minimum Tax obligations. Tax Consequences of NQDC for the Employer, in TAXATION AND FUNDING OF NONQUALIFIED DEFERRED COMPENSATION 41-43 (Marla J. Aspinwall and Michael G. Goldstein, eds., 2d ed. 2012). 
insured employee, gains are taxed at that point, resulting in deferral of tax but not exemption. ${ }^{146}$

While Congress has acted several times to limit abusive, leveraged COLI plans, ${ }^{147}$ few steps have been taken to address the fundamental tax advantages arising from COLI. The Pension Protection Act of 2006 is a notable exception. That act created I.R.C. $§ 101(j)$, which curtails the exclusion of death benefits in the case of employer-owned life insurance. COLI death benefits are now excluded from income only if the universe of insured employees is limited to directors and the top $35 \%$ of earners and insured employees provide informed written consent. Congress has not acted, however, to curtail the benefit of deferral of tax on the cash value build up within these plans. ${ }^{148}$

While tax advantaged, COLI products are expensive and complex. ${ }^{149}$ Firms purchasing these policies are paying for insurance, in addition to a tax-preferred investment vehicle. And one source noted that it can take up to a year to put a COLI in place. ${ }^{150}$ A further potential drawback is that investment options within a COLI vehicle are generally limited and may not perfectly match the options available to plan participants. ${ }^{151}$ One source suggested as a general matter that COLI use is prevalent for large plans with large obligations since the tax benefits offset the

${ }^{146}$ Frederick \& Mitchell Interview, supra note 103, noting that many firms using COLI fail to reap the full tax advantages since they tend to liquidate policies to satisfy plan obligations before death benefits are paid.

${ }^{147}$ Leveraged COLI plans, often covering thousands of employees (and generally having little or nothing to do with nonqualified deferred compensation), were a popular tax shelter during the 1980s and 1990s. In a typical arrangement, a plan sponsor would pay premiums using a combination of death benefits, dividends, and loans from the insurance company derived from the cash value build up within the plan. Deduction of interest and fees could turn a pre-tax losing arrangement into a post-tax winner. Leveraged COLIs of this type were eliminated through a combination of IRS litigation victories, based primarily on antiabuse principles, and a change of law in 1996 that significantly limited the deductibility of interest on COLI-backed loans. Because money is fungible, it remains possible for firms to indirectly leverage COLI arrangements. See Jennifer L. Brown, The Spread of Aggressive Corporate Tax Reporting: A Detailed Examination of the Corporate-Owned Life Insurance Shelter, 86 ACCT. REV. 23, 23-25 (2011) (describing the leveraged COLI shelter and legislative and judicial responses); Mark P. Gergen, The Logic of Deterrence: Corporate Tax Shelters, 55 TAX L. REV. 255, 256-57 (2002) (same); BAIRD WEBEL \& DONALD J. MARPLES, ConG. RESEARCH SERV., RL33414, Corporate-OWNEd LifE InSURANCE (COLI): INSURANCE AND TAX ISSUES (Jan. 21, 2011) (describing and analyzing evolving COLI tax rules).

148 As discussed more fully in text accompanying infra note 179 , legislation has been offered as recently as 2003 that would, with limited exceptions, require employers to include COLI cash value build up in income on an annual basis and eliminate exclusion of death benefits.

${ }^{149}$ COLI purchase also introduces counterparty risk, which can be significant given the long time horizons involved. Nunn, supra note 64, at 202.

${ }^{150}$ Frederick \& Mitchell Interview, supra note 103

${ }^{151}$ Neuwirth Interview, supra note 110. 
administrative costs and other drawbacks. ${ }^{152}$ Another source suggested that COLI use is actually declining among his clients. ${ }^{153}$

Ultimate Investment of Set Aside Funds. From a joint tax perspective, the important questions here involve the extent of COLI use and the ultimate investment of set aside funds. The two surveys suggest extensive use of COLI. Fifty-four percent of firms that informally fund and responded to MullinTBG's survey reported using COLI, 42\% taxable securities, and 19\% cash. ${ }^{154}$ Obviously, some firms combine these. Newport Group's survey respondents indicated even more overlapping use of funding mechanisms for DC plans with $73 \%$ using COLI to some extent, 39\% taxable mutual funds, 14\% bonds, $13 \%$ company stock, and 11\% separately managed investment accounts. ${ }^{155}$ Sources, however, suggested that these surveys likely overstate COLI use. Sources estimated that funding was divided about 50/50 between COLI and taxable securities. ${ }^{156}$ Generally, these taxable securities would be held in a rabbi trust, but, as noted above, the interposition of a rabbi trust has no impact on joint tax consequences.

Companies appear to only rarely informally fund nonqualified deferred compensation liabilities with their own stock. Thirteen percent of Newport Group's survey respondents reported funding DC obligations to some degree with their own stock, while none reported funding DB liabilities in this fashion. ${ }^{157}$ One source estimated that less than $10 \%$ of funds set aside are in company stock. ${ }^{158} \mathrm{He}$ explained that when participant notional investment is in company stock and will be paid in stock, firms often set aside shares to fund the obligation, but when notional stock investment will be paid in cash, firms generally do not set aside shares because doing so does not offset the income statement volatility. ${ }^{159}$ Thus, it is not surprising that if participant notional investment in stock is modest to begin with, informal funding in company stock is even more modest. ${ }^{160}$

\footnotetext{
152 Neuwirth Interview, supra note 110.

153 Frederick \& Mitchell Interview, supra note 103.

154 MullinTBG Survey, supra note 109, at 9.

155 Newport Group Survey, supra note 37, at 53.

156 Frederick \& Mitchell Interview, supra note 103; Interview with Executive Benefits Consultants with an International Firm, supra note 39.

157 Newport Group Survey, supra note 37, at 53. Company stock was not listed as an informal funding vehicle used by MullinTBG Survey responders, but it is not clear whether this should be interpreted as zero use of company stock, a failure to list company stock as an option on the survey, or something else. It is unlikely, however, that funding with owncompany stock is prevalent for MullinTBG Survey responders, given the silence.

158 Shannon Interview, supra note 103.

${ }^{159}$ Shannon Interview, supra note 103. Alternatively, plan sponsors may hedge cash-settled notional own-company stock investments with mutual funds that approximate the performance of the shares. COMPLEMENTING RESTRICTED STOCK, supra note 69.

${ }^{160}$ It is interesting to compare the use of own-company stock to fund nonqualified plan obligations to its use in funding qualified plan obligations. While ERISA rules cap owncompany stock holdings at $10 \%$ of qualified DB plan assets, until recently own-company
} 
With the exception of own-company stock, it is reasonable to assume that funds set aside by nonqualified DC plan sponsors are ultimately invested in such a way as to mirror as closely as possible the notional investment portfolios of participants. This follows from plan sponsors' emphasis on managing the income statement volatility arising from the liabilities, and should generally be true whether the funding vehicle is a COLI or a taxable account.

It is less obvious how amounts set aside to fund DB liabilities would ultimately be invested. The Newport Group survey suggests that firms commonly use COLI to fund these obligations, and that among taxable investments, mutual funds are employed about twice as often as bonds. ${ }^{161}$ Of course, the fact that twice as many sponsors utilize taxable mutual funds as bonds does not tell us that the ratio of dollars is two to one, but it does suggest a mix of debt and equity is held outside of COLI accounts.

Non-Set Aside Funds. What happens to deferred dollars that are not set aside to meet plan liabilities? These funds are used in the business, often substituting for borrowing. One source noted that in deciding whether or to what extent to fund, his clients typically look at one of three benchmarks for returns on non-set aside funds - their borrowing costs, return on cash investments, or internal rate of return. ${ }^{162}$ The appropriate benchmark would depend on a firm's particular circumstances.

\section{Joint Tax Consequences of Nonqualified Plans in Practice}

The joint tax consequences of nonqualified plans in practice are a function of employer actual use of deferred amounts as compared with counterfactual participant investment outside the plan. In the analysis that follows, I use notional participant investments in DC plans as a proxy for these hypothetical outside investments. In cases in which sponsors informally fund DC plan obligations, I generally assume that the instruments are the same, e.g., equity hedging equity or debt hedging debt.

The one exception to this is that not all notional investment in own-company stock is hedged with company stock given the fact that gains or losses on stock held to hedge notional stock investments do not flow through to income statements. The $\S 1032$ tax advantage is limited to the extent of sponsor hedging with own-company stock. Suppose, for example, that IBM employees notionally invest nonqualified DC accounts in IBM stock and that IBM purchases S\&P 500 index funds as a hedge, placing these index funds in a taxable account. Participants will receive cash benefits based on IBM's return, but IBM will pay tax at its regular rates on index

stock accounted for half of qualified DC plan assets for almost $20 \%$ of participants in the largest plans. See infra Part IV(E).

161 Newport Group Survey, supra note 37, at 53.

162 Neuwirth Interview, supra note 110. 
fund gains and losses and dividends. The joint tax advantage or disadvantage in this case would be determined by comparing IBM's tax rate on the index fund investment with participants' counterfactual tax rate on outside investments in IBM stock (or other equities, which is largely the same).

In cases in which sponsors do not informally fund nonqualified plan obligations, taxation of business returns is compared with counterfactual participant investment in debt or equity securities, as suggested by DC notional investments.

In the analysis that follows, I assume that corporations and individuals generally are taxed at the highest U.S. marginal rates, ${ }^{163}$ and I add the net investment income surtax to individual rates. I assume that COLI returns are taxed at a zero rate, despite the suggestion of one source that COLI policies are often liquidated prematurely. ${ }^{164}$ I ignore the possibility that individuals use life insurance products to reduce taxes on outside investments. ${ }^{165}$ While comparing COLI funded deferred compensation with fully taxable outside investment might be considered an apples to oranges comparison, it is the assumption that maximizes the joint tax advantage I am attempting to identify and helps us appreciate the worst-case scenario from the perspective of the public fisc. Moreover, there is no particular reason to match COLI funded deferred compensation with insurance-based outside investment. Any individual willing to absorb the cost can reduce taxes on his or her savings by investing through life insurance products.

163 Given the effective prohibition under I.R.C. $\S 409 \mathrm{~A}$ on offshore rabbi trusts, it seems reasonable to analyze non-COLI-based employer investments using U.S. corporate income tax rates. Of course, the effective marginal tax rate on U.S. income may be less than the top marginal rates as a result of NOLs. See infra Part IV.A.3.

${ }^{164}$ As discussed in text accompanying supra notes 91-94, the marginal rates assumed are as follows:

Individual: long-term capital gains and dividends, 25\%; interest and short-term capital gains, $44.6 \%$.

Corporate: own stock gains and COLI returns, 0; dividends, 10.5\%; capital gain, interest, and business profits, $35 \%$.

These rates are likely to change under the Trump administration, but at this point the impact of the joint tax consequences of nonqualified deferred compensation are unclear.

COLI policies that are liquidated prematurely would still provide the benefit of tax deferral, but not exemption. The tax benefit, however, would be offset by the unrecovered cost of the insurance.

As noted supra note 94, I follow previous commentators in ignoring the impact of state local income taxes on the joint tax analysis.

165 Michael J. GraetZ \& Deborah J. Schenk, Federal Income TaXation, Principles and Policies 159-61 (7th ed. 2013) (describing the preferential tax treatment (and limitations) associated with life insurance contracts). 
To place the following analysis in perspective, note that DC commitments probably represent about half of total nonqualified deferred compensation obligations currently, ${ }^{166}$ but that the DC fraction is increasing over time.

\section{Defined Contribution Plans}

As an initial matter, let us assume that about $50 \%$ of deferred DC sums are set aside by plan sponsors to meet future obligations. ${ }^{167}$ Sources suggest that no more than $10 \%$ of dollars set aside by plan sponsors (perhaps $5 \%$ of total DC commitments) are invested in own-company stock to hedge stock-based obligations to participants. The joint tax advantage is large. A plan sponsor pays no tax on gains on its own stock; the participant would have paid tax at individual rates topping out at $25 \%$. But the $\S 1032$ advantage is currently being enjoyed on only about $5 \%$ (and unlikely to be more than 10\%) of total DC balances.

\begin{tabular}{|l|l|l|}
\hline Employer & Participant & Joint Tax Advantage \\
\hline Own stock: $\mathrm{t}=0$ & Own stock: $\mathrm{t}=25 \%$ & $25 \%$ \\
\hline
\end{tabular}

Sources suggest a roughly even split between the use of COLI and taxable securities in funding plan obligations. ${ }^{168}$ If so, roughly a quarter of total commitments would be funded with COLI. These COLI dollars are used primarily to hedge the income statement volatility of participant notional investments, so in aggregate COLI contain a mix of debt and equity mirroring participant investment. It appears, however, that firms are somewhat less likely to fund the debt side of participant portfolios. If so, COLI likely hold somewhat more equity than a 40/60 overall debt/equity notional investment estimate would suggest. In any event, use of a COLI does generate a joint tax advantage. That advantage is greater if the counterfactual investment would be individual investment in debt securities (or short term capital gains), but it is significant, nonetheless.

\begin{tabular}{|l|l|l|}
\hline Employer & Participant & Joint Tax Advantage \\
\hline COLI: $\mathrm{t}=0$ & Equity: $\mathrm{t}=25 \%$ & $25 \%$ \\
COLI: $\mathrm{t}=0$ & Debt: $\mathrm{t}=44.6 \%$ & $44.6 \%$ \\
\hline
\end{tabular}

The use of taxable securities to fund nonqualified DC commitments results in mixed joint tax consequences. Long-term capital gains are taxed at a higher rate to corporations than to individuals (35\% versus $25 \%$ ), while interest, dividends, and short-term capital gains are taxed at a lower rate (interest and short-term capital

166 Jackson \& Honigsberg found that DC balances accounted for $44 \%$ of total nonqualified deferred compensation for senior executives in 2011. Jackson \& Honigsberg, supra note 39, at 491-92.

167 Sources suggest that over $50 \%$ of plan sponsors set aside funds to manage DC obligations but firms frequently fund less than $100 \%$ of those obligations, so $50 \%$ of dollars set aside seems a reasonable assumption.

168 Supra text accompanying notes 154-156. 
gains: $35 \%$ versus $44.6 \%$; dividends: $10.5 \%$ versus $25 \%$ ). Sources suggest that firms are more likely to set aside funds to hedge the equity-side of notional portfolios, but returns to equity in the form of long-term capital gains are tax disadvantaged, while short-term capital gain and dividend returns are tax advantaged. In aggregate, dividends have accounted for over almost half of S\&P 500 company returns over the long haul and a somewhat lesser percentage of U.S. equity returns overall. ${ }^{169}$ Nonetheless, without further data, it would appear that the joint tax consequences of notional equity investment hedged with taxable securities are roughly neutral. 170

\begin{tabular}{|l|l|l|}
\hline Employer & Participant & Joint Tax Advantage \\
\hline Taxable LTCG: $\mathrm{t}=35 \%$ & LTCG: $\mathrm{t}=25 \%$ & $(10 \%)$ \\
Taxable divs: $\mathrm{t}=10.5 \%$ & Divs: $\mathrm{t}=25 \%$ & $14.5 \%$ \\
Taxable debt: $\mathrm{t}=35 \%$ & Debt: $\mathrm{t}=44.6 \%$ & $9.6 \%$ \\
\hline
\end{tabular}

Finally, we have the roughly $50 \%$ of deferred DC dollars that are left in the business. These dollars are associated with notional debt and equity investments of participants that may be somewhat more debt-heavy than our overall $40 \%$ debt/60\% equity benchmark, because firms are somewhat more likely to leave debt obligations un-hedged.

Assuming that the appropriate tax rate on business profits is $35 \%$ (and that business returns roughly mirror market returns), the parties face a joint tax disadvantage on equity held in participant portfolios (both long-term gains and dividends: $35 \%$ corporate versus $25 \%$ individual) and a joint tax advantage on debt returns (35\% corporate versus $44.6 \%$ individual).

\begin{tabular}{|l|l|l|}
\hline Employer & Participant & Joint Tax Advantage \\
\hline Business: $\mathrm{t}=35 \%$ & Equity: $\mathrm{t}=25 \%$ & $(10 \%)$ \\
Business: $\mathrm{t}=35 \%$ & Debt: $\mathrm{t}=44.6 \%$ & $9.6 \%$ \\
\hline
\end{tabular}

These joint tax consequences are summarized in the graphic that follows. Joint tax advantage is good from the point of view of the private parties, hence green, and joint tax disadvantage is bad, hence red. Neutral is yellow. More intense colors represent larger joint tax advantage or disadvantage. For simplicity, I have assumed a 60/40 equity/debt split and that equity returns are an equal mix of

${ }^{169}$ Adam Johnson, Show Me the Money: Why Dividends Matter, BloomBerG (Sept. 10, 2014, 11:52 AM), http://www.bloomberg.com/news/articles/2014-09-10/show-me-the-moneywhy-dividends-matter (calculating that dividends accounted for $46 \%$ of the total return on the S\&P 500 between 1989 and 2014).

${ }^{170}$ It is in the context of sponsor funding with taxable securities (and the context of unfunded liabilities which follows) that any change in marginal rates adopted during the Trump administration will be most consequential for the joint tax analysis of nonqualified deferred compensation. 
dividends and long-term capital gains. Obviously, this chart reflects only a rough approximation of joint tax consequences in practice.

\section{Nonqualified DC Plans - Joint Tax Consequences in Practice}

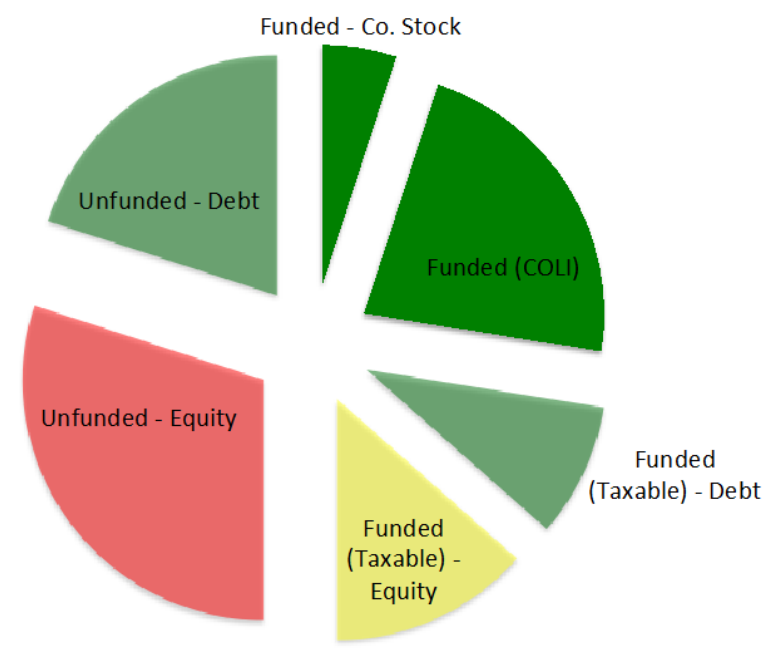

\section{Defined Benefit Plans}

Although DB plans are declining in importance, many Fortune 500 executives are grandfathered into DB plans, and DB plans will likely continue to be important in certain industries, such as utilities. There are no notional participant investments and there is little income statement volatility associated with these plans, and, as a result, they are less likely to be funded. It seems likely that well under $50 \%$ of DB obligations are funded.

Companies do not report using their own shares as a funding mechanism for DB plans, so $\S 1032$ plays little or no role here. However, firms often do use COLI products to fund DB liabilities. Half or even three-quarters of dollars funding DB liabilities may be invested through COLI, likely generating a joint tax benefit.

\begin{tabular}{|l|l|l|}
\hline Employer & Participant & Joint Tax Advantage \\
\hline COLI: $\mathrm{t}=0$ & Equity: $\mathrm{t}=25 \%$ & $25 \%$ \\
COLI: $\mathrm{t}=0$ & Debt: $\mathrm{t}=44.6 \%$ & $44.6 \%$ \\
\hline
\end{tabular}

The remaining set-aside funds are invested in a taxable fashion, which may or may not result in a joint tax benefit. Interest and dividends are taxed at a lower rate to companies than individuals; long-term capital gains are taxed at a higher rate. 


\begin{tabular}{|l|l|l|}
\hline Employer & Participant & Joint Tax Advantage \\
\hline Taxable LTCG: $\mathrm{t}=35 \%$ & LTCG: $\mathrm{t}=25 \%$ & $(10 \%)$ \\
Taxable divs: $\mathrm{t}=10.5 \%$ & Divs: $\mathrm{t}=25 \%$ & $14.5 \%$ \\
Taxable debt: $\mathrm{t}=35 \%$ & Debt: $\mathrm{t}=44.6 \%$ & $9.6 \%$ \\
\hline
\end{tabular}

As in the case of DC plans, firm use of deferred DB dollars in their business operations may result in a joint tax advantage or disadvantage, depending on the counterfactual outside investment by participants. The corporate tax rate applicable to business earnings is greater than the individual rate on long-term capital gains and dividends (joint tax disadvantage) but lower than the individual rate on interest and short-term capital gains (joint tax advantage).

\begin{tabular}{|l|l|l|}
\hline Employer & Participant & Joint Tax Advantage \\
\hline Business: $\mathrm{t}=35 \%$ & Equity: $\mathrm{t}=25 \%$ & $(10 \%)$ \\
Business: $\mathrm{t}=35 \%$ & Debt: $\mathrm{t}=44.6 \%$ & $9.6 \%$ \\
\hline
\end{tabular}

These joint tax consequences of nonqualified DB plans in practice are portrayed in the graphic that follows. As before, I have assumed a 60/40 equity/debt split and that equity returns are long-term capital gains. Again, this chart reflects only a rough approximation of joint tax consequences in practice.

\section{Nonqualified DB Plans - Joint Tax Consequences in Practice}

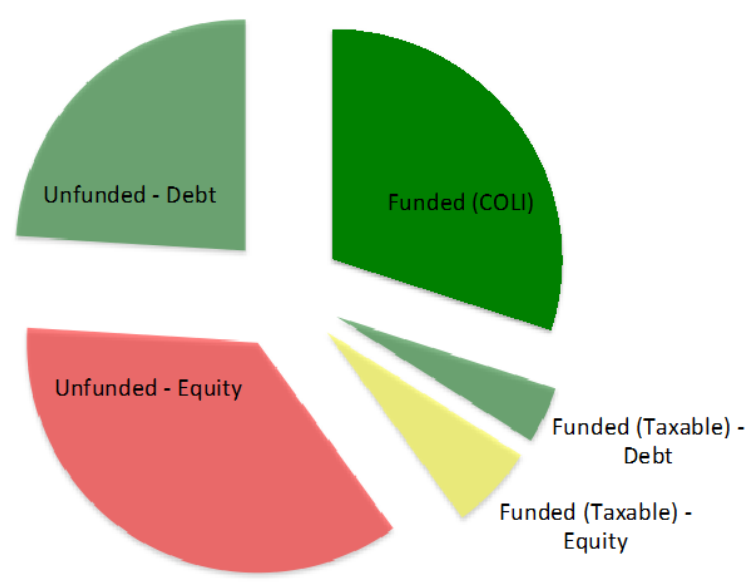




\section{Discussion}

\section{A. Is There a Joint Tax Advantage Issue to Worry About, and, If So, What Is It?}

It is not clear that the joint tax advantage enjoyed by nonqualified deferred compensation participants and sponsors justifies reform of the basic tax rules. On the other hand, it may be worth considering reform targeted at COLI use.

\section{I.R.C. § 1032}

Section 1032 is less relevant to nonqualified deferred compensation practice than one might surmise. ${ }^{171}$ Diversification concerns deter participants from tying deferred compensation returns to own-company stock and accounting concerns tend to deter sponsors. As discussed below, apparently no more own-company stock is set aside to informally fund nonqualified deferred compensation liabilities than has historically been contributed to qualified plan trusts, despite the fact that $\S 1032$ provides a tax advantage only with respect to nonqualified plan contributions. ${ }^{172}$

To be sure, some firms may hold treasury shares that are not specifically allocated to informally funding nonqualified deferred compensation liabilities, and these firms may have deferred compensation liabilities that exceed amounts set aside in rabbi trusts or COLI accounts. Should we assume a zero employer rate of tax on nonqualified deferred compensation to the extent that a firm holds treasury shares and has unfunded liabilities? In my view we should not. If treasury shares are held for another reason - to provide a pool for issuing restricted stock or options or because firm management thought its shares undervalued and a good investment - and if we posit that these shares would be held irrespective of any deferred compensation liabilities, then it does not make sense to effectively treat these treasury shares as funding deferred compensation. Of course, we generally cannot be certain whether there is or is not a connection absent an explicit tie, but given the prevalence of informal funding arrangements, it seems sensible to assume that unfunded liabilities are indeed unfunded.

\section{COLI}

The largest source of joint tax advantage in private-sector nonqualified arrangements likely stems from the use of COLI to informally fund these plans. The prevalence of COLI use is, in fact, consistent with a story in which plan sponsors fail to minimize joint tax burdens through investment decisions. If, for example, firms were using $\S 1032$ to minimize the joint tax burden of nonqualified deferred

${ }^{171}$ Recall that under $\S 1032$ companies pay no tax on gains or losses on own-company stock. See supra text accompanying note 55 .

172 Infra text accompanying notes 212-217. 
compensation, there would be no need to purchase COLI. As noted, firms pay a price to gain the COLI tax advantage, but apparently the tax benefit outweighs the cost at many companies. And even if the potential COLI tax benefit is often not fully realized because of premature policy liquidations, the use of COLI raises legitimate tax policy concerns with respect to high-income taxpayer subsidy, cost to the public fisc, and potential distortions in compensation design.

On the other hand, one could argue that the COLI tax advantage simply parallels the tax benefit available to individuals who use life insurance products as savings vehicles. ${ }^{173}$ My impression is the use of COLI as an investment vehicle may be more common than individual investment through insurance products, but it is difficult to distinguish tax motivated individual investing from insurance acquisition, and ultimately this is an empirical question. Moreover, whatever one thinks of the market failure arguments put forward to justify tax preferences for individual purchase of life insurance, these arguments do not extend to COLI. ${ }^{174}$

One could also argue that the COLI issue is separable from the nonqualified deferred compensation issue per se. COLI is widely used to fund various employee benefits, such as health care benefits, and for other purposes, such as providing "key man" insurance. ${ }^{175}$

Nonetheless, I would argue that social welfare would be enhanced by limiting or eliminating the tax benefits of COLI as used to fund nonqualified deferred compensation and similar employee benefits. This is not the appropriate forum for exhaustive prescription and analysis, so I will simply sketch out possible avenues of attack. Luckily, several are already in the public record.

As discussed above, there are two main tax issues associated with COLI - the underlying tax benefits of deferral and exemption and the additional tax arbitrage associated with leveraged arrangements. Tax savings from direct leverage borrowing tied directly to cash value build up - have been all but eliminated. Under current law, interest is deductible on no more than $\$ 50,000$ of COLI-based debt with

173 Whole life and other long-term insurance arrangements involve a savings element in addition to insurance. Investment gains under these policies are excluded from income when received as death benefits, IRC $\S 101(\mathrm{a})$, and, although the rules are more complex, as a practical matter, investment gains generally are excluded from income even when amounts are withdrawn prior to death. GRAETZ \& SCHENK, supra note 165, at 159-61.

${ }^{174}$ It is sometimes argued that individuals systematically underestimate the risk and cost of death and that adverse selection undermines accurate insurance pricing, but these concerns, even if valid, do not translate to COLI. WEBEL \& MARPLES, supra note 147, at 6-7. Of course, companies and insurance providers will argue that preferential COLI tax treatment is needed to incent firms to provide nonqualified deferred compensation and other employee benefits. But Congress has already decided that non-qualified plans should not be tax advantaged, so this argument should carry little weight.

175 WEBEL \& MARPLES, supra note 147, at 1. 
respect to at most 20 individuals at a particular company. ${ }^{176}$ But indirect leverage is still possible. Firms may borrow money for other purposes and deduct the interest on those borrowing while simultaneously holding COLI policies with large cash values. The Obama administration attempted to combat this indirect leverage by limiting the deductibility of employer interest payments based on the ratio of COLI cash values to total firm assets, whether or not the debt was incurred to purchase or carry the COLI, and irrespective of the identity of the insured employees. ${ }^{177}$ This proposal has not been adopted by Congress but remains on the shelf.

The second COLI tax issue has to do with deferral of tax on investment income and exclusion of death benefits, the "normal" tax preferences associated with investing through insurance products. If one concludes that these preferences are not warranted for COLI type arrangements, they should simply be eliminated. ${ }^{178}$ In 2003, Representative Rahm Emanuel offered legislation in the House that would have done just that. Under that legislation, with certain specific exceptions for, e.g., "key man" insurance, employers would have been required to include income earned on COLI products each year, and death benefits in excess of premiums paid and gains already taxed would have been fully includable, as well. ${ }^{179}$ If these reforms were to be enacted, presumably COLI would disappear as a means of informally funding nonqualified deferred compensation, while, of course, tax neutral rabbi trusts would remain.

\section{Low Marginal Tax Rate Employers}

The use of nonqualified deferred compensation by governmental and other formally tax-exempt organizations raises a distinct set of issues and is not a focus of this Article. ${ }^{180}$ However, the use of nonqualified deferred compensation by private

176 I.R.C. § 264(a)(4), (e) (2012). See also WEBEL \& MARPLES, supra note 147, at 3-4.

177 Proposal to Modify the Tax Treatment of Corporate-Owned Life Insurance Continues to Receive Attention, WR Newswire, An AALU WASHIngton Report (Feb. 3, 2014), http://rosestreetadvisors.com/wp-

content/uploads/sites/22/2016/02/022014ProposaltoModifytheTaxTreatmentofCOLICon tinuetoReceiveAttention.pdf; WEBEL \& MARPLES, supra note 147, at 4.

178 The use of COLI has already been circumscribed to some extent by recent legislation. The "COLI Best Practices Act," part of the Pension Protection Act of 2006, restricts the full tax advantage (tax free death benefits) to policies insuring directors, five percent owners, and the $35 \%$ most highly compensated employees, and also requires employers to obtain informed consent prior to taking on policies on insureds. I.R.C. § 101(j) (2012); Pension Protection Act of 2006, Pub L. No. 109-280, § 863(j), 120 Stat. 786 (Aug. 17, 2006).

179 H.R. 2127, 108th Congress, 1st Session (2003). See also WEbEL \& MARPLES, supra note 147 , at 11 .

180 This is not to suggest that these issues are unimportant, and under recently proposed regulations, their importance may grow. Unfunded, nonqualified deferred compensation offered by tax-exempt entities (other than churches) is regulated under IRC $\S 457$ and consists of "eligible plans" regulated under $\S 457$ (b) and "ineligible plans" regulated under $\S$ 
sector firms that are effectively tax exempt, or that face low effective marginal tax rates generally, is fair game and is potentially troubling from a tax policy perspective. The returns on investments at these firms face little or no tax, which might incent these firms to shift current compensation into deferred compensation, and impose a cost on the public fisc that we might wish to recover through accrual taxation or a special tax on nonqualified plan investment returns. ${ }^{181}$

Further work is needed to determine how widespread a problem this really is and whether the effort involved in specifying and identifying low marginal tax rate companies and excessive use of nonqualified deferred compensation by these companies would be worth it. ${ }^{182}$ Preliminary investigation, however, suggests that

457(f). $§ 457(b)$ eligible plans provide limited deferral opportunities that mirror private sector nonqualified deferred compensation, but, because the plan sponsor is tax-exempt, § 457(b) plans produce after-tax results similar to those achieved through qualified plans. However, excluding "catch-ups," the maximum $\S 457$ (b) contribution for 2015 was $\$ 18,000$ per employee. IRS, Pub. No. 4484, TAX EXEMPT AND Government Entities EMPloyeE Plans (2015). § 457(f) ineligible plans provide for unlimited deferral, but taxation is imposed at the point at which deferred amounts are no longer subject to a substantial risk or forfeiture (SROF). See also Mark P. Altieri, Nonqualified Deferred Compensation Plans, 75 CPA J. 54, (2005); Kilgour, supra note 27, at 179 . In the wake of the enactment of $\S 409 A$, which incorporates a rather strict definition of SROF and IRS Notice 2007-62, which suggested an intent to apply that definition to $\S 457(\mathrm{f})$ plans, some practitioners and commentators assumed that elective deferred compensation would be taxed on an accrual basis (although tax on the earnings would be deferred). Doran, supra note 12, at 5 n. 21; Polsky, supra note 40 , at 640 n. 24 . However, proposed regulations issued in June 2016 adopt a more flexible definition of SROF, providing that certain non-competition agreements can create a SROF and specifically recognizing that elective deferral is not inconsistent with a SROF in certain situations. I.R.S. Reg. 147196-07, 2016-28 I.R.B. See also Amy S. Elliott \& Andrew Velvarde, Treasury Finally Issues Deferred Comp Rules for Tax-Exempts, 2016 TAX NoTES TODAY 120-1, available at http://www.taxnotes.com/tax-notes-today/benefits-and-pensions/treasuryfinally-issues-deferred-comp-rules-tax-

exempts $/ 2016 / 06 / 22 / 18521201$ ?highlight=treasury $\% 20$ finally $\% 20$ issues $\% 20$ deferred $\% 2$ 0comp\%20rules (June 22, 2016). Assuming that the proposed regulations are adopted essentially as drafted, we may see increased tax-advantaged deferrals by or on behalf of exempt organization employees.

181 There is precedent for applying accrual taxation to nonqualified deferred compensation paid by tax-indifferent organizations. See I.R.C. § 457(f) (including "ineligible" deferred compensation of employees of tax-exempt entities in gross income in the first year in which there is no substantial risk of forfeiture); § 457A (2012) (applying accrual taxation to vested nonqualified deferred compensation paid by, e.g., foreign companies unless substantially all income is effectively connected with a U.S. trade or business or is subject to a comprehensive foreign income tax). However, identification of effectively tax-exempt domestic firms may be somewhat more difficult than identification of tax indifferent foreign firms.

182 The existing literature examining the relationship between firm tax status and use of nonqualified deferred compensation is slim and relies on rough proxies for company marginal tax rates. These studies typically find no statistically significant relationship. See Kelli A. Alces \& Brian D. Galle, The False Promise of Risk-Reducing Incentive Pay: Evidence 
firms facing low effective marginal tax rates may not be exploiting the opportunity to minimize their joint tax bills on executive retirement savings through use of nonqualified deferred compensation.

I analyzed contributions to nonqualified defined contribution accounts for fiscal year 2012 by the "top five" senior executives of the companies included in the Compustat Execucomp database, and by employers on behalf of these executives. ${ }^{183}$ Deferred compensation by and on behalf of these executives is reported in annual proxy statements. For each firm, I calculated the aggregate of executive and employer contributions as a fraction of aggregate total compensation for these individuals. ${ }^{184}$ Next, I accessed estimated U.S. effective marginal federal income tax rates (EMTRs) for each firm from two sources: 1) estimates produced using the methodology developed by Jennifer Blouin, John Core, and Wayne Guay and provided in the Compustat database, 185 and 2) estimates determined by John Graham, which are available through his website. ${ }^{186}$ Although largely similar in approach, the two sources often provide significantly different estimates. Given this, I sorted the firms into three categories - those with a U.S. EMTR of 0.10 or less according to the estimates of both Graham and Blouin, Core, and Guay (low EMTR firms), those with an EMTR of 0.30 or more according to both estimates (high EMTR firms), and all others. For the low EMTR group of firms, total NQDC contributions averaged only $0.48 \%$ of total compensation ( 0 median), while total NQDC

from Executive Pensions and Deferred Compensation, 38 J. CoRP. L. 53, 99 (2012) (including NOL level and taxes paid as variables); Wei Cen, The Determinants of CEO Inside Debt and its Components 30 (Working Paper, Jan. 2011) (employing an NOL indicator variable); Rangarajan K. Sundaram \& David L. Yermack, Pay Me Later: Inside Debt and its Role in Managerial Compensation, 57 J. Fin. 1551, 1574, Table VI (2007) (same).

183 Of course, the five most highly compensated executives at each firm would generally be a subset of the population eligible to participate in nonqualified deferred compensation programs, but this is the only data that is publicly available. The Compustat Execucomp database is accessible through the Wharton Research Data Service: https://wrdsweb.wharton.upenn.edu/wrds/.

184 Total compensation is measured per Execucomp variable TDC1.

185 Jennifer Blouin et al., Have the Tax Benefits of Debt Been Overestimated?, 98 J. Fin. Econ. 195 (2010). In a nutshell, Blouin, Core, and Guay (BCG) develop a nonparametric (nonrandom walk) approach to estimating a firm's future taxable income that can be used to determine the total present value of current and future U.S. federal income taxes associated with an additional dollar of income today. Using accounting data, they calculate effective marginal tax rates both before and after deductions for interest, the latter being the appropriate rate for incremental decision-making with respect to matters such as use of nonqualified deferred compensation. The BCG effective marginal tax rate database is available through Compustat. BCG's estimation approach is a refinement of that developed in John R. Graham, Debt and the Marginal Tax Rate, J. FIN. ECoN. 41 (1996).

An implicit assumption in utilizing either BCG or Graham's marginal tax rate data is that the income generated on deferred compensation is taxed in the U.S. Given the effective prohibition under I.R.C. $\S 409 \mathrm{~A}$ on offshore rabbi trusts, this seems a reasonable assumption, at least for a large fraction of deferred compensation.

186 https://faculty.fuqua.duke.edu/ jgraham/ 
contributions averaged $4.24 \%$ of total pay for the high EMTR group of firms $(0.68 \%$ median). ${ }^{187}$ Despite the potential joint tax advantage, participation in nonqualified deferred compensation at low EMTR firms appears to be relatively meager. ${ }^{188}$

I plan to investigate the relative paucity of nonqualified deferred compensation participation at low marginal rate firms in future work, but three potential explanations come immediately to mind. First, some firms with low effective marginal rates may be on shaky ground financially, in which case executives might be loath to defer current compensation in exchange for an unsecured promise to pay in the future. Second, nonqualified deferred compensation use varies by industry and industry effects may explain part of the picture. Third, consistent with recent survey evidence provided by John Graham, Michelle Hanlon, Terry Shevlin, and Nemit Shroff,, ${ }^{189}$ some firms may not take their low effective marginal tax rates into account in deciding how aggressively to push nonqualified deferred compensation.

Further work may sharpen or even flip this picture. After controlling for firm size, industry, etc., it may turn out that low effective marginal tax rate firms do exploit the nonqualified deferred compensation opportunity. Even if that turns out to be the case, however, as discussed below, it seems likely that shareholders enjoy the benefit of the tax savings on deferred dollars at low marginal tax rate firms, not plan participants. ${ }^{190}$ If so, this distributional consequence would not alleviate all of the concerns associated with tax-preferred nonqualified deferred compensation use by low effective marginal tax rate employers but would mitigate the concern that the subsidy flows to high-income taxpayers.

With respect to taxable plan sponsors facing marginal tax rates at or near the statutory maximum, and setting COLI use aside, nonqualified deferred compensation in practice seems to yield little or no aggregate joint tax advantage.

187 The difference in means is statistically significant at the $1 \%$ level. 62 firms satisfied the low EMTR criteria; 492 satisfied the high EMTR criteria.

188 Data from other years yields a pattern that is generally consistent with the 2012 data discussed herein.

${ }^{189}$ John R. Graham et al., Tax Rates and Corporate Decision Making (Working Paper, March 2016) (evaluating survey responses from tax executives at 500 companies subject to the U.S. corporate tax and finding that most firms use either the U.S. statutory tax rate or their GAAP effective tax rate (an average rate) instead of effective marginal tax rates in making incremental decisions). To be sure, while statutory rates will generally be larger than marginal rates, the GAAP effective rate can be larger or smaller than the marginal rate.

${ }^{190}$ Infra Part IV(B) (arguing that nonqualified DC plan participants generally enjoy effective above-market returns whether employed by tax-paying or effectively tax-exempt employers and that shareholders bear the costs, if any, associated with taxation of gains on deferred amounts held by employers). 
Of course, one might take a different tack entirely and argue that the policy focus should be on potential joint tax advantage, not realized advantages. The fact that a firm fails to realize a potential joint tax advantage in this area might simply reflect better after-tax opportunities elsewhere. For example, firms that fail to fully hedge nonqualified liabilities notionally invested in dividend paying equities seem to be squandering the benefit of the dividend received deduction, but might just have better uses for the funds.

One response to this line of argument is that firms often do set aside assets to satisfy nonqualified plan liabilities and sometimes the result is a clear joint tax disadvantage, such as when firms hedge notional investment in growth stocks with taxable funds. Another response is that the concerns of those advocating for a special tax or accrual taxation are less in evidence when, for example, a firm invests freed up assets in its business generating robust but relatively high-tax returns rather than hedging participant notional investments at relatively low rates. Where is the cost to fisc, subsidy of high-earner savings, or distributional concern in that scenario?

\section{B. What Are the Distributional Consequences of Deferred Compensation?}

Nonqualified defined contribution plan terms typically mirror those of qualified plans, such as $401(\mathrm{k}) \mathrm{s}$, promising participants returns on their notional investments that are undiminished by tax during the deferral period; i.e., tax-free growth. Nominally, participants gain an advantage - the difference between preand post-tax returns ${ }^{191}$ - and shareholders bear the cost of providing this tax-free investment growth to plan participants, to the extent that the firm incurs taxes on the returns on the deferred dollars. Many plan sponsors also match participant deferrals to some degree or make other contributions to nonqualified accounts. But one may question whether or to what extent these benefits are shifted back to the firm and shareholders through adjustments to other terms of compensation.

The short answer is that we don't know the distributional consequences of these arrangements. However, for several reasons, I am skeptical that the nominal benefit of tax-free growth on deferred dollars is shifted away from plan participants. First, the population of participants is heavily weighted in favor of a firm's most

191 The advantage can be substantial when returns are substantial. Applying the assumptions employed by Professors Halperin and Warren in their example, an executive deferring compensation in a nonqualified plan operating under these terms could accumulate $30 \%$ more assets over ten years than she could by investing after-tax pay in the same instrument. See Appendix. To be sure, Halperin and Warren employ a $10 \%$ annual pre-tax rate of return to simplify their example, a return that has not been generally achievable for some time. On the other hand, they also assume a 30\% individual marginal tax rate, which exceeds the top effective rate on individual equity returns but is far less than the current top effective rate on debt returns. The net advantage to participants in these plans increases with pre-tax returns and with individual tax rates. 
highly compensated and most powerful employees. Second, the cost of providing what are effectively above-market returns is not specifically disclosed to shareholders. Firms are required to disclose above-market returns accruing on deferred compensation accounts held by their most senior executives, but returns that match those available under qualified plans are not considered above-market returns for the purposes of these disclosures, even if plan sponsors incur greater costs in delivering these returns on nonqualified accounts. ${ }^{192}$ Third, DC plan participation is largely elective and by no means universal. It would be difficult for firms to adjust other terms of compensation to offset the deferred compensation return advantage when less than half of eligible individuals elect to defer compensation in any given year. ${ }^{193}$ Fourth, some firms provide explicitly abovemarket returns on nonqualified deferred compensation. ${ }^{194}$ It would seem odd for firms subject to investor scrutiny to provide such visible benefits through the front door and then to remove them surreptitiously through the back door. Fifth, to repeat, most nonqualified DC participants are getting the same deal as $401(\mathrm{k})$ participants. The dollars are larger and the firm tax consequences are less favorable, but firms are unlikely to adjust other terms of employment to offset this obscure advantage when the arrangement seems comparable on the surface to a 401(k).

Of course, at firms that are effectively tax-exempt or that face very low effective marginal rates, there would be little or no cost to providing tax-free growth on nonqualified deferred compensation dollars for the shareholders to bear. But I see no reason to think that plan participants would realize a better deal at these firms; no reason, in other words, to think that the firm-level tax benefit would flow through to participants. Of course, it might. Plans might be more generous or other compensation terms more generous at these firms, reflecting the tax savings on nonqualified deferred compensation, but this seems unlikely. Absent evidence to this effect, it seems sensible to assume that shareholders, not participants, enjoy the tax savings at these firms.

In sum, it seems likely that DC plan participants enjoy returns that are undiminished by tax during the deferral period. In some cases, providing this return results in no cost to shareholders. This would be the case at effectively tax-exempt firms and at tax paying firms to the extent that participants and sponsors take

192 SEC, REG. S-K, COMPLiance \& Disclosure Interpretations $§ 219.01$ (Jan. 24, 2007) ("A registrant need not report earnings on compensation that is deferred on a basis that is not tax qualified as above-market or preferential earnings within the meaning of Item 402(c)(2)(viii)(B) where the return on such earnings is calculated in the same manner and at the same rate as earnings on externally managed investments to employees participating in a tax-qualified plan providing for broad-based employee participation.").

193 Newport Group Survey, supra note 37, at 21 (reporting that 46\% of eligible individuals elected to defer compensation in 2013).

${ }^{194}$ In my sample of 40 S\&P 500 companies with active nonqualified deferred compensation plans, two provided explicitly above-market returns. 
advantage of IRC $\S 1032$. In other cases, shareholders likely bear a cost that may be relatively low (e.g., when COLI products are employed) or quite significant (e.g., when participant accounts are hedged with taxable investment in securities.

I also suspect, but am less confident, that employer matching contributions made to nonqualified DC accounts are not offset by other terms of employment. All of the arguments favoring participant retention of above-market returns apply to employer contributions except for their visibility. These contributions, to the extent received by the NEOs, are explicitly disclosed in a prominent table in company proxy statements. In this sense, matching contributions are similar to other perquisites that are received by senior executives and are disclosed. The difference, I think, is that executive participation in qualified $401(\mathrm{k})$ and nonqualified $401(\mathrm{k})$ supplemental programs seems egalitarian compared to many disclosed perks, such as use of company cars and planes. As a result, investors may be more likely to view company matching dollars as an expected incident of employment, not an added give-away to executives.

The distributional consequences of nonqualified DB plans are also somewhat unclear, but it remains likely that participants win, while shareholders lose or break even. As with nonqualified DC plans, nonqualified DB plans often mirror the terms of the corresponding qualified DB plans. The terms of the plans incorporate the tax advantages of qualified plans. And, again, other compensation terms are unlikely to be adjusted because the benefit is not disclosed and is obscure, and because participation is focused at the top of the corporate hierarchy. On the other hand, nonqualified DB plans tend not to be elective, making it easier for employers to adjust other terms of employment, if they were to choose to do so.

To be sure, nonqualified plan participants pay a price for their above-market returns and employer matching dollars. Even if their notional investments are diversified, these individuals remain unsecured creditors and face the risk of total loss of nonqualified benefits in the event of company bankruptcy. And, given $\S 409 \mathrm{~A}$, it is much more difficult to protect against this possibility than it was formerly. ${ }^{195}$ However, participation in nonqualified plans is almost entirely voluntary. Use of these plans indicates that the perceived benefits outweigh the risks. ${ }^{196}$

\section{What Role Do Taxes Play in the Adoption or Operation of Nonqualified Deferred Compensation Arrangements?}

\footnotetext{
195 Supra Part I(C).

${ }^{196}$ Should the SEC mandate disclosure of effective above-market returns provided to nonqualified deferred compensation participants? In principle, they should, but estimation of the benefit would be complex as it depends on rates of return achieved over the deferral period as well as on current and projected individual tax rates. Given the apparently limited impact of executive pay disclosures on the magnitude of executive pay (see Walker, supra note 75 , at 246 ), it is not clear that the benefits of such disclosure would justify the costs.
} 
Consistent with the forgoing analysis, I see little evidence suggesting that the joint tax consequences of nonqualified deferred compensation arrangements are of first order importance in the decision to offer these plans or in the selection of investments. If joint tax consequences were the driving force one would expect to see programs structured to encourage notional and actual investment in the types of instruments that yield a large joint tax advantage - company stock, income stocks, and debt securities. But there is little evidence of this. Own-company stock appears to be used at least as commonly in qualified plans, where $\S 1032$ provides no incremental benefit, as in nonqualified plans. ${ }^{197}$ Sources suggested that typical nonqualified DC notional investment portfolios are somewhat more debt heavy than those found in 401(k)s. This might suggest tax-motivated allocation of debt instruments to nonqualified plans, but these allocations are also consistent with shorter expected investment horizons for riskier unsecured nonqualified plan investment, so this is not strong evidence that taxation is of first order importance. There is no evidence suggesting that income stocks represent a greater proportion of nonqualified plan portfolios than they do of retirement portfolios more generally. All indications suggest that DC plan notional investment menus are designed to meet the long-term savings needs of participants, nothing more.

When asked whether "compensat[ing] executives in a more tax-efficient manner," was an important goal for their nonqualified benefits programs, $18 \%$ of respondents to the Newport Group's survey reported that this was critical, while $52 \%$ rated this goal as very important. ${ }^{198}$ My source at the Newport Group explained, however, that this goal referred to tax efficiency from the executives' perspective. ${ }^{199}$ Firms think it important to provide their executives and highly compensated employees with expanded qualified plan-type savings opportunities. This was not meant to be a question about joint tax consequences, and my contact did not think it likely that survey respondents interpreted it that way. ${ }^{200}$

Having decided to offer a nonqualified plan, joint tax considerations clearly play an important role, at a certain level. Companies will not intentionally trigger $\S 409 \mathrm{~A}$, and sources reported that consulting opportunities have increased in the wake of $\S 409 A^{\prime}$ s enactment, given the additional complexity and high stakes associated with missteps. ${ }^{201}$ Reportedly, the use of COLI boils down to simple economics, trading off the tax benefits of COLI against its cost and other constraints.

However, as noted above, notional investment choices and actual use of deferred amounts do not reflect joint tax minimization. In this area as in many others, accounting considerations appear to be as or more important than tax.

\footnotetext{
197 Infra text accompanying notes 212-214.

198 Newport Group Survey, supra note 37, at 7.

${ }^{199}$ Shannon Interview, supra note 103.

200 Shannon Interview, supra note 103.

201 Interview with Executive Benefits Consultants with an International Firm, supra note 39.
} 
Professor Doran has suggested that another tax rule, IRC $\S 162(\mathrm{~m})$, could help explain the prevalence of nonqualified deferred compensation. ${ }^{202}$ Under $\S 162(\mathrm{~m})$, the deduction for non-performance based compensation paid to a public company's CEO and the three most highly compensated executives other than the CEO is limited to $\$ 1$ million per executive per year. Deferring salary or other nonperformance-based compensation in excess of $\$ 1$ million until an executive is no longer one of these "covered employees" would allow a firm to deduct otherwise nondeductible pay. Doran also notes that executives who are residents of states with high state income tax rates can defer compensation until they retire to a low (or no) tax state and reduce or eliminate the state income tax burden. ${ }^{203}$

It is certainly possible that these tax rules influence the use of nonqualified deferred compensation. Indeed, it seems likely that executives would take potential state income tax burdens into account in their personal planning. I am somewhat skeptical that $\S 162(\mathrm{~m})$ plays a significant role, given that it applies only to four individuals at each company, that most compensation other than annual salary can be readily designed to satisfy the "performance based" exception to nondeductibility, and the fact that participants, not firms, generally elect whether to defer compensation and for how long. But these are empirical questions, and, in any event, even if nonqualified deferred compensation is being used to maximize deductibility under $\S 162(\mathrm{~m})$ or avoid state income taxes, it's not clear that either would justify reform of deferred compensation taxation, per se. ${ }^{204}$

\section{Why (Else) Do Firms Offer Nonqualified Deferred Compensation?}

Over $80 \%$ of firms responding to the Newport Group's survey reported that it was critical or very important "to allow executives to accumulate assets for their financial planning needs" and "to have a compensation program that is competitive with peer companies." 205 Interview responses supported paternalism and competition as the leading drivers of nonqualified programs. ${ }^{206}$ But sources also suggested that these programs are in flux. Paternalism may remain an important factor in some industries (utilities were frequently mentioned) but less so for start-

\footnotetext{
202 Doran, supra note 62.

203 Doran, supra note 62, at 23-24 (describing the federal legislation that protects certain retirement income from out-of-state taxation). See also supra note 107 (discussing how the details of this statute may influence the design of nonqualified DC plans).

204 As Doran notes, and as others have recognized, the limitation on deductibility under $\S 162(\mathrm{~m})$ is poor tax policy. Full deductibility of compensation is consistent with general tax principles, and the $\S 162(\mathrm{~m})$ limitation was a misguided attempt to shape compensation practices through the tax code. Doran, supra note 62 at 51. Doran finds avoidance of state tax more objectionable, and I agree, but arguably the root problem is the federal law that pre-empts out-of-state taxation of certain retirement income. Id. at 23.

205 Newport Group Survey, supra note 37, at 7.

206 Interview with Executive Benefits Consultants with an International Firm, supra note 39 (competition); Telephone Interview with Michael T. Schoonmaker, Principal, Ernst \& Young [hereinafter Schoonmaker Interview] (Feb. 23, 2016) (paternalism).
} 
ups and firms in the tech and financial industries. ${ }^{207}$ Rational, utility-maximizing executives should not need a company-sponsored plan to put away assets for retirement or college expenses.

On the other hand, if I am right about the distributional effects of nonqualified plans, participants enjoy an opportunity to invest on terms that are not generally available. Recall that plans do not merely provide participants with the after-tax returns achievable by their employers on deferred sums, but returns that are wholly undiminished by tax during the deferral period. As detailed in the Appendix, applying the assumptions employed by Professors Halperin and Warren in their example, an executive deferring compensation in a nonqualified plan operating under these terms could accumulate 30\% more assets over ten years than she could by investing after-tax pay in the same instrument. ${ }^{208}$ Moreover, it is certainly not a bad thing, from the perspective of boards and executives, that the opportunity to achieve tax-free growth on nonqualified deferred compensation portfolios does not factor into the calculation of total "top 5" compensation that is prominently disclosed in annual proxy statements. While this paper does not argue that managerial power drives the use of nonqualified deferred compensation, the failure to treat this yield advantage as an above-market return requiring disclosure under SEC rules is consistent with the preference for low salience pay under the managerial power view. ${ }^{209}$

Path dependence may also play a role. Nonqualified deferred compensation arrangements date back at least to World War II when top individual tax rates peaked at 94\%, while corporate tax rates topped out at $40 \% .{ }^{210}$ Although usage of nonqualified deferred compensation remained fairly modest prior to the adoption of qualified plan limitations in the $1980 \mathrm{~s},{ }^{211}$ companies and executives would have enjoyed large joint tax advantages on nonqualified arrangements throughout this period. Today, absent COLI, that driving force is often lacking, but once a compensation practice that benefits executives has become commonplace, it can be

\footnotetext{
207 Schoonmaker Interview, supra note 206.

208 As noted supra, Halperin and Warren employ a 10\% annual pre-tax rate of return to simplify their example, a return that has not been generally achievable for some time. On the other hand, they also assume a 30\% individual marginal tax rate, which exceeds the top effective rate on individual equity returns but is far less than the current top effective rate on debt returns. The net advantage to participants in these plans increases with pre-tax returns and with individual tax rates.

${ }^{209}$ See supra note 76 for a very brief description of the managerial power view of the processes involved in setting executive compensation.

${ }^{210}$ Christopher Drew \& David Cay Johnston, Special Tax Breaks Enrich Savings of Many in the Ranks of Management, NYT $($ Oct. 13, 1996) (noting that "many companies began letting executives defer pay as the highest tax rate surged from 7 percent to 94 percent during World War II).

${ }^{211}$ Id. (discussing the adoption of limitations on 401(k) contributions in 1986 and on pension plans in 1988 and 1993).
} 
difficult to eradicate, particularly when the benefits are poorly disclosed and not salient.

Finally, while I am skeptical that executives can accurately predict their future marginal tax rates, elective plans do provide participants an opportunity to make a bet on lower individual rates at retirement (either due to a change in the brackets or their position within the brackets), if they wish to do so. Some executives might find this option to be valuable, and firms might respond to executives' demand for that option.

\section{E. A Final Mystery? Relative Use of Own-Company Stock in Qualified and Nonqualified Deferred Compensation Plans}

It is interesting to compare notional investment of nonqualified deferred compensation in own-company stock and informal funding of nonqualified plan obligations with own-company stock with qualified plan investment in owncompany stock. Historically, at least, one would find as much or more own-company stock in qualified as in nonqualified plans. Between 1985 and 1998, 14\% of total DC qualified plan assets of a broad sample of firms were invested in own-company stock on average. ${ }^{212}$ In 2002, more than $50 \%$ of employee assets were invested in own-company stock at 18 of the largest 100 corporate qualified DC plan sponsors. $^{213}$ In 2005, $17 \%$ of participants in qualified DC plans administered by Vanguard had over $20 \%$ of their balances invested in company stock. ${ }^{214}$

From a joint tax perspective, this seems odd. There is a significant cost in terms of lost diversification to investing in own-company stock, ${ }^{215}$ a cost that should dampen the appetite for own-company stock in retirement plans. While $\S 1032$ results in a joint tax advantage for own-company stock investment in nonqualified plans, and could offset the diversification cost to some degree, it provides no incremental benefit for own-company stock placed in qualified plans. ${ }^{216}$ Qualified plan trust assets grow tax free in any event. ${ }^{217}$ Of course, not all employees have

\footnotetext{
212 Joshua D. Rauh, Own Company Stock in Defined Contribution Pension Plans: A Takeover Defense?, 81 J. Fin ECon. 379, 388, table 3 (2006).

213 Rauh, supra note 212 , at 382.

214 Stephen P. UtKus \& Jean A. Young, Vanguard Group, The Evolution of Company Stock in DEFined Contribution Plans 5 (May 2014). Holdings of company stock in qualified DC plans has declined since the enactment of the Pension Protection Act of 2006, which requires public company plan sponsors to allow participants to diversify employer stock contributions after three years and their own contributions at any time. 26 C.F.R. $\S$ 1.401(a)(35)-1 (2016); UTKUS \& YoUnG, supra, at 3.

215 Benartzi et al., supra note 74 , at 50 , put the cost at roughly fifty cents on the dollar.

${ }^{216}$ Halperin \& Warren, supra note 32, at 326 (noting that the relative advantage created by qualified plan exemption of investment returns depends on the tax treatment of an asset class outside of a qualified plan).

217 During the deferral period, earnings on own-company stock face a zero tax rate whether held in a qualified plan trust or in a segregated account informally funding a nonqualified
} 
access to both qualified and nonqualified plans, but from a joint tax perspective it is surprising that own-company stock would be used as or more heavily in qualified plans as in nonqualified plans.

A number of commentators have attempted to explain the use of owncompany stock in qualified plans. At one level, the use is attributable to employer contributions in stock and to plan structures, such as defaults, that encourage employee investment in stock. ${ }^{218}$ But why do firms structure plans in this way and why do employees accept these defaults, given the cost to diversification? Professors Benartzi, Thaler, Utkus, and Sunstein conclude that employees underestimate the risk of holding employer stock while employers overestimate the benefits in terms of enhanced productivity. ${ }^{219}$ But if so, why are notional nonqualified plan investments in company stock lower? Is it because more sophisticated executives are more sensitive to the value of diversification?

Professor Joshua Rauh has offered a corporate governance explanation for the use of company stock in qualified plans. ${ }^{220}$ He observed that stock held in qualified plan accounts is in friendly hands in the event of a corporate control contest as workers, who may fear job losses, are likely to vote with management. Rauh found that state law changes that increased takeover protections were associated with reduced own-company stockholdings in 401(k)s. ${ }^{221}$

While Benartzi and colleagues conclude that the magnitude of Rauh's results was not large, 222 Rauh's story could help explain why a relative tax advantage fails to drive own-company stock out of qualified plans and into nonqualified plans. Unlike own-company stock held in a qualified plan trust that would be voted by the trustee (or the employee if the vote is passed along), notional investment in employer stock within a nonqualified plan is simply a bookkeeping entry that affords no voting rights. Moreover, any funds set aside by the sponsor and actually invested in own-company stock yields non-voting Treasury stock. In short, owncompany stock "investment" in nonqualified plans provides no takeover protection.

On the other hand, the accounting impediments - the inability to hedge income statement volatility arising from participant notional investment in owncompany stock in nonqualified DC plans - are not a factor with respect to actual investment in employer stock within qualified plans. There is both more of a pull

plan liability. The difference is that other asset classes are also zero taxed while held in qualified plan trusts but face positive tax rates backing nonqualified plan obligations, unless a COLI is used.

218 Rauh, supra note 212 , at 380.

${ }^{219}$ Benartzi et al., supra note 74, at 68.

${ }^{220}$ Rauh, supra note 212 , at 390.

${ }^{221}$ Rauh, supra note 212 , at 380.

222 Benartzi et al., supra note 74, at 61. 
(entrenchment) and less of a brake (accounting) associated with own-company stock investment in qualified plans. ${ }^{223}$

\section{Conclusion}

The real world tax consequences of complex nonqualified deferred compensation programs depend significantly on employer and employee practices. Unfortunately, currently mandated corporate disclosures shed only limited light upon these practices. However, interviews with participants and industry surveys provide insights that suggest that the joint tax consequences of nonqualified deferred compensation are mixed, at least with respect to programs sponsored by taxable and tax-paying employers. The use of corporate owned life insurance as an informal funding vehicle for nonqualified deferred compensation results in a joint tax advantage, of greater or lesser extent depending on when policies are cashed in, but funding liabilities with taxable securities or plowing deferred amounts back into the business is as likely to result in a joint tax disadvantage as an advantage. This evidence suggests that, while COLI use and taxation may deserve another look by policy makers, the driving force behind fundamental reform of nonqualified deferred compensation taxation may be limited. Moreover, while loss firms facing low effective marginal rates can create a joint tax advantage through use of nonqualified deferred compensation, preliminary investigation suggests that they rarely do so. Perhaps the heightened risk associated with an unsecured promise to pay outweighs the potential tax savings at loss firms.

Even if nonqualified deferred compensation does not turn out to be a substantial drain on the public fisc, this Article has argued that it likely provides an undisclosed advantage to corporate executives, as it provides what are effectively above-market returns on retirement savings. As a result, it appears that shareholders, not taxpayers, often subsidize nonqualified deferred compensation. The SEC should consider revising its rules to mandate disclosure of this advantage.

\footnotetext{
223 There are other differences that might help explain greater use of employer stock in qualified plans, and two of them are tax differences. First, in-kind distributions of company stock from 401(k)s may be tax preferred. In a nutshell, if company stock held in a qualified plan is delivered to a participant as stock, only the market value at the time of the contribution is taxed as ordinary income; gains are taxed as capital gains and are deferred until disposition. By contrast, proceeds received on the distribution of mutual funds held in $401(\mathrm{k})$ and other qualified plans (that are not Roth plans) are fully taxed at ordinary income rates when withdrawn from the plan (or from a rollover IRA). I.R.C. $\S 402(\mathrm{e})(4)(B)$ (2012); Benartzi et al., supra note 74 , at 50 . Second, employers can deduct certain reinvested dividends paid on stock held in qualified plan trusts. I.R.C. $\S 404(\mathrm{k})$ (2012); Benartzi et al., supra note 74, at 59-60. On balance, however, the similarities and differences in the use of employer stock in qualified and nonqualified plans reinforce the conclusion that joint tax consequences are second order considerations in the operation of these plans.
} 


\section{Appendix}

Illustration of the joint tax consequences of nonqualified deferred compensation from Halperin \& Warren (2014) at 328. (The following example is simplified, excluding the demonstration that the timing of the employer's deduction does not affect the joint tax consequences.) ${ }^{224}$

Employee E has the opportunity to receive $\$ 100,000$ in current compensation from employer ER, when E's tax rate on all sources of income and gain is $30 \%$ and ER's is $20 \%$. If E invested the after-tax amount $(\$ 70,000)$ at an annual pretax return of $10 \%$, E would have $\$ 137,701$ in ten years $\left(\$ 70,000 \times 1.07^{10}\right)$.

Now suppose that $E$ agreed to forgo $\$ 100,000$ in current compensation in exchange for a payment in ten years. ER's deduction is deferred as required by current law. Holding ER's Year 0 position constant, ER can set aside $\$ 80,000$ in Year 0 , which would compound to $\$ 172,714\left(\$ 80,000 \times 1.08^{10}\right)$ in ten years. That amount would permit ER to pay E a deferred amount of $\$ 215,892$ after taking into account the tax benefit $(\$ 43,178)$ of the compensation deduction, leaving EE with $\$ 151,124$ after tax.

The advantage to $\mathrm{E}$ from deferral is $\$ 13,423(\$ 151,124$ $\$ 137,701$ ), which is due to the investment compounding at the employer's after-tax rate rather than the employee's after-tax rate (that is, $\left.\$ 70,000 \times\left(1.08^{10}-1.07^{10}\right)=\$ 13,423\right)$.

In practice, employers often promise nonqualified plan participants returns that are equivalent to those achievable with qualified plans, i.e., returns undiminished by tax during the deferral period. Assuming that costs and benefits are not redistributed through other terms of compensation, the impact on E and ER in Halperin and Warren's example scenario would be as follows.

E agrees to forgo $\$ 100,000$ in current compensation in exchange for a payment in ten years. The notional investment compounds at a $10 \%$ rate yielding $\$ 259,374$ at payout $(\$ 100,000 \mathrm{X}$ $1.10^{10}$ ), leaving E with $\$ 181,562$ after taxes, an advantage of $\$ 43,861$ (or $32 \%$ ) versus E's outside investment opportunity.

The after-tax cost to ER of providing a payment of $\$ 259,374$ is $\$ 207,499$, resulting in a $\$ 34,785$ (20\%) funding shortfall versus the $\$ 172,714$ compound after-tax balance on the set aside funds.

\footnotetext{
${ }^{224}$ Halperin and Warren provide a corresponding algebraic demonstration. Halperin \& Warren, supra note 32, at 328-29 n. 33.
} 